\title{
Accounting for Extractive Industries: has IFRS 6 harmonized accounting practices by extractive industries?
}

\author{
Dr Hafez Abdo \\ 618, Newton Building \\ Nottingham Business School \\ Burton Street \\ Nottingham, NG1 4BU \\ Email: hafez.abdo@ntu.ac.uk \\ Tel: 0044 (0)115 8486098
}




\section{Introduction}

The globalized nature of the extractive industries and the political, economic and strategic impact of mineral wealth on mineral-rich countries as well as the needs of different stakeholders for transparent information drive the need for a common accounting practice for these industries (Wise and Spear, 2000). This is particularly important because, in most cases, mineral-rich countries, such as the Arab Gulf and African countries, lack mining capital and/or expertise. Additionally, new countries and companies are entering the extractive industries, which are international by definition but the terminology, definitions, principals, and classifications are different from one country to another (Wise and Spear, 2010). Stakeholders outside the industry, such as banks, investors and financial and academic analysts, need to understand these differences.

Accounting is meant to record economic facts and reflects individual, organizational and social reality; it expands on being a "tell it like it is" to construct, explain and interpret these realities (Gallhofer and Haslam, 2007). Therefore accounting as being a system of informing and disclosing, highlights and makes things more visible to stakeholders. Diversity in accounting practices restricts the comparability of financial statements of companies in the same sector (Dunne et al., 2009), making it difficult for shareholders and potential investors to make informed investment decisions. With the growth and the globalization of international capital markets and the globalization of investments the financial statements comparability problem has become an international concern (Sutton, 1993; Roberts et al., 2008). Investors, analysts, regulators and other stakeholders require transparent and internationally comparable financial statements (Glaum et al., 2013).

In response to these demands, the International Accounting Standards Board (IASB) has, over many years, been working on reducing the diversity in accounting practices by developing international accounting standards. These standards are an attempt by the IASB to harmonize accounting treatments of different expenditures and revenues among companies and countries and to provide significant advantages to individual stakeholders and corporations alike (Choi and Levich, 1991; Whittington, 2000). According to Sutton (1993) 
and Gallhofer and Haslam (2007), international accounting standards are appropriate tools for providing uniformity in accounting practices by different companies around the world.

In his paper, we investigate the extent to which the IASB, via introducing IFRS 6 , has been successful in harmonizing accounting practices among firms in the extractive industries sector around the world. In other words, the objective of this study is to investigate to what extent has IFRS 6 been a successful standard in harmonizing accounting practices among extractive industries. A reasonable understanding of the successfulness of the IFRS 6 in harmonizing accounting practices by mining industries should allow the IASB and other stakeholders to define factors that restrict this success and possibly to facilitate mechanisms that derive a worldwide acceptance and enforcement of the IFRS 6.

The extractive industries have historically used a number of different methods for accounting for their expenditures, including successful efforts, full costing, area of interest, appropriation and reserve recognition accounting (Alfresdson et al., 2009). This use of a variety of accounting methods presented problems for investors comparing different companies in the extractive sectors. Thus, in 2004, the IASB developed and published an accounting standard, IFRS 6, for the extractive industries, whose objective is to enhance the uniformity of accounting practices and improve the comparability of financial statements. IFRS 6 allows the use of two alternative accounting methods: the successful efforts and full costing methods. These methods differ primarily in terms of which exploration and evaluation (E\&E) expenditures are capitalized. While E\&E expenditures are capitalized under the full costing method, they are only capitalized under the successful efforts method if it can be determined that it leads to commercially viable discoveries. However, there is currently no evidence to suggest that companies in the extractive industries are fully compliant with IFRS 6 and, therefore, whether IFRS has been successful in harmonizing accounting practices in the extractive industries. The extant literature has tended to focus only on the universality of the historical development of regulatory attempts to account for the extractive industries (see for example, Flory and Grossman, 1978; Luther, 1996; Gallhofer and Haslam, 2007; Cortese et al., 2009 and 2010; Cortese and Irvine, 2010; Cortese, 2011) and not the role of IFRS 6 in harmonizing accounting practices for extractive industries.

The two widely used accounting methods, successful efforts and full costing do not provide a common basis for financial performance comparison between different companies. Until the 
IFRS 6 has been issued, there has been no IFRS that specifically address accounting practices for the extractive industries. Thus, there has been an urgent need for an accounting standard that allows comparisons to be made by harmonizing accounting terminology, concepts and practice between different extractive companies (IFRS Foundation, 2010). To get this harmonization in place compliance by extractive companies with the standard is a key requirement. From this gap in the literature, the following research questions have derived:

1- To what extent has the IFRS 6 been a successful standard, introduced by the IASB, in harmonizing accounting practice for extractive industries worldwide?

2- What are the drivers of this success, if there has been any?

3- What are the challenges to the success of the IFRS 6 in harmonizing accounting practices for extractive industries?

This paper attempts to bridge this gap in the literature by investigating the implementation of IFRS 6 in the upstream oil and gas sector, which is the largest sub-sector in the extractive industry. While building on previous studies, the paper aims to contribute to the literature by shedding light on the role of IFRS 6 in harmonizing accounting practices among extractive industries and hence on benefiting stakeholders in making a like-with-like comparison among companies in the same sub-sector of the extractive industries.

In order to achieve the described objectives and answer the specified research question this paper is structured as follows: The paper commences with a discussion of previous similar studies, followed by brief explanation of the investment activities of firms in the extractive industries to illustrate the nature of these investments and to clarify the role that accounting plays in this process. The following section provides a brief overview of the two most widely used methods of accounting for the extractive industries, SE and FC, and stresses the need for a greater harmonization tools for accounting practices in these industries. Section 4 focuses on the specific requirements of IFRS 6 and section 5 details the research approach before a discussion and analysis of the data is presented in section 6. Section 7 presents a conceptualization of the different methods of accounting used by extractive industries. A final section will conclude the paper. 


\section{Similar studies}

Most of the studies on IFRS 6 have focused on the standard-setting process and the ethical considerations that surround the process of creating this standard (Cortese et al, 2009; Cortese et al, 2010). However, there is a dearth of studies that tackle the success, or otherwise, of IFRS 6 in providing a blanket accounting treatment for expenditures incurred by extractive companies in the pre-development stage of investment. The following is a narration of a number of studies that tackle issues related to the IFRS 6 from different perspectives.

Luther (1996) studied characteristics of accounting for the extractive industries and explored salient issues in the relevant pronouncements and practices in five different countries: the USA, Australia, Canada, South Africa and the UK. Luther (1996: 67) concluded that accounting regulations in the extractive industries were limited in scope and inconsistent in perception; he added that "given the limitations of historical cost accounting, the cost of regulation and standardization (sic.) would not be justified" (1996: 86). Street and Gray (2004) investigated a number of financial statements of a worldwide sample of companies in order to explore extent of noncompliance with the International Accounting Standards (IAS). Street and Gray (2004) conclude that noncompliance with IAS was driven by a number of factors such as listing status of the companies studied, the type of auditing firms, the manner of reference to IAS in the accounting policies of the companies and the country of domicile of these companies. Similarly, Stadler and Nobes (2014) studied the influence of country, industry and topic factors on adopting IFRSs. They concluded that country factors have the greatest influence on IFRS policy choice. Furthermore, Street and Gray (2004) reported that compliance with IASs, in terms of disclosure and measurements, by mining companies was one of the highest ( $82 \%$ and $94 \%$ respectively) among the companies they investigated. Cortese et al. (2009) researched the economic consequences of different accounting methods applied in the extractive industries; they concluded that although debate among different international accounting bodies has been ongoing for some time and although attempts have been made to harmonize accounting practices for the mining industries, few regulations have emerged, and the choice of one of a number of accounting methods still needs to be made. Noël et al. (2010) used a Habermasian philosophy to explore the procedures at work in international accounting standard-setting from an ethical point of view to analyze the political problems associated with adopting IFRS 6. They concluded that neither the IASB's way of working nor the composition of its board fulfilled the criteria of discourse ethics. Furthermore, Noël et al (2010: 339) stated that “...international accounting standard-setting 
depends largely on the interest relationship between the dominant economic actors and grants experts too much importance". Cortese et al (2010) applied a Critical Discourse Analysis (CDA) tool to the process of setting IFRS 6 . They concluded that IFRS 6 simply codifies the current industry accounting practices and provides much flexibility to extractive companies in choosing the reporting method as they see fit. Cortese et al $(2009 ; 2010)$ claim that while IFRS 6 provides a comfortable practice for extractive industries, it does not meet the espoused objectives of accounting standards in facilitating the creation of financial reports that provide guidance to stakeholders in making economic decisions. Cortese and Irvine (2010) examined the role of the powerful extractive entities in shaping IFRS 6. They concluded that the contributions of these entities might not always be visible but that their influence certainly existed. The result of their role, according to Cortese and Irvine, was the issuance of IFRS 6, which not only allowed the existing accounting practices of extractive industries to continue but also codified these practices, thereby granting them some legitimacy. This last view agrees with Gallhofer and Haslam (2007) as they see that IFRS 6 in fact opted for flexibility in accounting practices. Cortese (2011) studied attempts to standardize oil and gas accounting practices in the UK since the 1970s using a regulatory capture perspective and concluded that because accounting regulators have been captured by industry constituents, standard setting efforts have always failed to offer a harmonized accounting practice for the extractive industries. Similar to Street and Gray (2004) Glaum et al., (2013) analyses compliance for companies from 17 European countries with disclosures required by International Financial Reporting Standards (IFRSs) focusing on IFRS 3 and IAS 36. Their study focused on companies' disclosures related to business combinations and impairments testing of assets. Glaum et al (2013) findings reveals that despite the adoption of IFRSs by European companies reporting practices continue to differ between these companies.

These studies contribute to our knowledge on a number of key areas surrounding IFRS 6, such as the following: the developmental history of accounting for extractive industries, the economic effects of using full costing or successful efforts methods on companies' financial statements, obstacles that prevent a clear cut harmonization of accounting practices for operations of extractive industries, factors that influence companies compliance with international accounting standards, and the evolution of IFRS 6 as a single accounting standard for extractive industries. However, none of these studies has examined the effectiveness of IFRS 6 in harmonizing accounting practices for mining industries. Whilst the 
other previous similar studies form a suitable basis for this research this study differs from them in a number of aspects. Because of the diversity and uniqueness of the mining industry the IFRS 6 has been engineered chiefly for this industry. Our research is not focused mainly on checking compliance of mining companies with the requirements of the IFRS 6; compliance is one of the focuses of this paper. The main focus is on whether the efforts of the IASB to harmonize accounting practices by mining companies by issuing the IFRS 6 has been successful. Therefore, this study aims to bridge that gap in the literature through an interpretive approach using qualitative content analysis of the accounting policies, financial statements and notes on the financial statements of a number of extractive companies as being disclosed in their annual reports.

\section{Accounting for the extractive industries}

\subsection{Extractive Industry Investment Cycle}

Investment in the extractive industries involves five distinct stages: acquisition, exploration, evaluation, development and production. Each of these stages is characterized by unique activities and requires varying levels of finance and technical operations while being subject to differing types of risk (Wise and Spear, 2002; Cortese et al., 2009; Cortese, 2011). Undertaking an investment decision at any stage requires careful consideration because the level of investment is likely to be significant, especially in regard to the cost of building the infrastructure necessary for production.

Following the identification of areas with possible commercial deposits, extractive companies will typically seek to acquire the right to explore, develop and produce any commercial minerals that may exist beneath that land (Gallun et al., 2001). The acquisition of a promising property is associated with a number of costs, such as the costs of initial geological and geophysical studies, test-well contributions, the purchase of support equipment and facilities, and licensing fees. Extractive companies bear these costs for establishing the possibility of existing commercial mineral resources before they may apply for exploration licenses. If signs are favorable that mineral resources may exist in commercial quantities, companies then apply for exploration licenses for the areas in question.

The exploration stage involves the identification of areas that may contain mineral resources. Geological and geophysical exploration studies are therefore essential for this stage. Seismic studies are also crucial for providing detailed information about sub-surface structures. By 
the time these studies are completed and if an area has proved to have probable reserves, an extractive company will then obtain a license from a host government to be able to undertake its exploration activities. Finding mineral resources does not guarantee that they exist in economically producible quantities. Therefore, extractive companies have to drill evaluation wells to be able to identify whether the reserves discovered have sufficient commercial potential to accommodate extraction (Luther, 1996; Gallun et al, 2001). Exploration costs are incurred to find mineral resources, while evaluation costs are incurred to facilitate an assessment of the technical feasibility and commercial viability of the discovered resources (Wise and Spear, 2002; PwC, 2011).

The development stage includes establishing the necessary infrastructure needed for extracting and transporting commodities. In other words, development expenditure involves drilling and completing wells, installing equipment, and connecting to a pipeline or tanker terminals. The required amount of money for investment at this stage is significant (Adelman, 1996).

After developing a field, an operator can start producing the minerals immediately if the economic environment and the necessary production conditions allow. Operating costs increase when the volume of reserves decreases because the amount of reserves in the ground determines the pressure dynamics of the reservoir. Production rate is negatively related to costs and positively related to prices (Gallun et al., 2001).

\subsection{Accounting methods for the Extractive Industries}

In accounting for investments in the extractive industries as discussed above, oil and gas companies have the option to choose among a number of methods, but the most common are the successful efforts method and the full cost method (Flory and Grossman, 1978; Cortese et al., 2009). These two methods differ as to which exploration and evaluation (E\&E) expenditures are capitalized; in other words the interpretation of the "tells it like it is" concept differs between these two accounting methods. This has historically lead to a significant controversy in the accounting literature over which of the two commonly used methods captures the underlying economic transaction (see Bryant, 2003). In general, this controversy relates, according to Flory and Grossman (1978), to both the physical attributes of mineral resource production and the financial impacts on the extractive industries. It is worth mentioning that both methods are allowed under the US GAAP: the successful efforts method is governed by Financial Accounting Standard 19 (FAS 19), and the full cost method is 
governed by the Security and Exchange Committee's Regulation S-X Rule 4-10 (Ernst \& Young, 2009).

\subsubsection{The Successful Efforts Method}

According to the successful efforts method, costs that can be assigned to successful discoveries that have commercial viability are capitalized on a field-by-field basis; other costs are generally charged to expenses. These capitalized costs are depreciated, depleted and amortized (DD\&A) over the estimated economic life of a given project on a field-by-field basis as production occurs ${ }^{1}$ (Noël et al., 2010; PwC, 2011). If the outcome of the discoveries is unknown, the operation costs are recorded in a holding account as work-inprogress/intangible assets and are then capitalized when the outcome of the operation is a success; otherwise, they should be expensed (Gallun et al., 2001). Thus, the SE method considers only those costs related to successful production as relevant to the generation of future revenues, while costs relating to unsuccessful production are considered expenses in the period in which they are incurred. Existing evidence reveals that larger, integrated and well-established extractive companies generally use this method of accounting (Flory and Grossman, 1978; KPMG, 2005; Deloitte, 2009). This is because writing off costs of unsuccessful explorations for these companies does not significantly influence their reported performance due to their financial capabilities.

\subsubsection{The Full Cost Method}

In contrast to the successful efforts method, under the full cost method of accounting for investments in the extractive industries, the costs of acquisition, exploration, evaluation and development are accumulated in a large geographic cost center and capitalized regardless of the outcomes of the extractive operations. These large cost pools are then depreciated, depleted and amortized (DD\&A) over the estimated economic life of the project on a cost center basis (usually geographically) as production occurs. ${ }^{2}$ This method takes the view that both successful and unsuccessful costs are related to the discovery of reserves and, therefore, must be capitalized and matched against future revenues instead of expensing them in the period in which they are incurred. Evidence shows that smaller extractive companies usually

\footnotetext{
${ }^{1}$ Under the FAS 19, total proven oil and gas reserves are used as a basis for the calculation of DD\&A for property acquisition costs, and proven developed reserves are used for the calculation of DD\&A for the cost of wells and equipment (Ernst \& Young, 2009).

${ }^{2}$ Rule $4-10$ of the SEC requires the use of total proven oil and gas reserves as a basis for calculating DD\&A (Ernst \& Young, 2009).
} 
use this method because it creates an enhancement effect on earnings (KPMG, 2005; Cortese et al, 2009; Howard and Harp, 2009; Noël et al, 2010; ICAI, 2013).

\subsubsection{Successful Efforts Method versus Full Cost Method—the debate}

The main difference between full cost and successful efforts methods is related to their treatment of pre-development expenditures, specifically expenditures incurred during the exploration and evaluation (E\&E) phase of mining investment. While pre-development expenditure is capitalized by full cost companies, this expenditure is capitalized by successful efforts companies only if it leads to commercially viable discoveries. Development expenditure is capitalized by both methods, as companies only develop reserves of mineral resources when they are certain the reserves contain commercially viable resources. Therefore, most of the debate regarding accounting for extractive industries centers on treatments of expenditures during the E\&E stages of investment.

While the two methods lead to different figures being reported in both the statement of comprehensive income and the statement of financial position, each of these methods has its proponents and opponents. Much of the debate centers on differing philosophical perspectives with regard to how assets are defined under each method. An asset, as defined by the IASB (2006), is "a resource controlled by the entity as a result of past events and from which future economic benefits are expected to flow to the entity" (IASB, 2006, online). On the one hand, under the successful efforts method, the costs of unsuccessful operations do not lead to future economic benefits as defined by IASB (2006) and are therefore expensed in the period in which they are incurred. On the other hand, the philosophy of the full cost method is that all pre-production costs are in fact part of the process of finding mineral resources; some of these costs will not lead directly to a successful discovery, but without them the business cannot be carried out (Flory and Gossman, 1978; Nikolai et al., 2009). In this context, what is classified as the cost of unsuccessful discoveries contributes indirectly to the successful finding of mineral resources. Hence, all related pre-production expenditures must be capitalized as an intangible asset in the balance sheet. In other words, while the successful efforts method considers that future economic benefits are generated only as a result of expenditure on successful discoveries, the full cost method contemplates future economic benefits that arise from total expenditure. Based on this account it can be claimed that the interpretation and application of the "telling it like it is" concept does differ between the two 
accounting methods and this obviously not making it easy to stakeholders particularly when it comes to making investment decisions.

Underpinning the debate is conflicting interpretations of the matching concept presented by the proponents of each method. The matching concept is predicated on the assumption that in measuring and reporting profits, revenues should be set against the necessary expenditure that generates them (Thomas and Ward, 2009). The proponents of the successful efforts method, the larger oil and gas producers, argue that the matching concept cannot allow expenditure that does not result in successful discoveries to be recognized in the statement of financial position as an asset and must be written off in the statement of comprehensive income as a period expense (Jones, 2010). In so doing, revenues from specific discoveries, the successful discoveries, are matched with costs that have a direct association with them, such DD\&A of capitalized expenditure and the general expenses in addition to production costs. In contrast, proponents of the full cost method, smaller oil and gas producers, note that the costs of unsuccessful discoveries are incurred to generate future revenues and must be matched with revenues from successful discoveries (Jones, 2010). Thus, the necessary expenditure to generate the future revenues is represented by the DD\&A of the total capitalized costs (both successful and unsuccessful) plus the production and other general costs. From this perspective, Bryant (2003) suggests that the full costing method is more consistent with the matching concept and provides measures of assets and earnings that are more consistent with the economic reality of the company.

\subsubsection{Method Choice Effects and the Need for Harmonized Treatment}

Regardless of which side of the debate one takes, the choice of accounting method has implications for how the financial statements are portrayed, and it therefore affects the decisions of investors. Three implications can be noted here. One, by capitalizing all costs and writing them off in portions of DD\&A against the revenues of the future successful discoveries, the full cost method results in reporting a stronger financial position and better financial performance than the successful efforts method. Therefore, in theory, full cost companies may be seen as stronger performers and find it easier to access external funds than successful efforts companies (Flory and Grossman, 1978; Deakin III, 1979). On the other hand, by expensing unsuccessful expenditures (the costs of dry holes) in the year in which they are incurred, the successful efforts method avoids overstating assets and smoothing income for the successful efforts companies, making them more prudent and, hence, less 
risky to invest in compared to full costing companies (Bryant, 2003). In addition, by capitalizing unsuccessful costs, the full cost companies only delay loss recognition by deferring the effects of expenses (Flory and Grossman, 1978; Price Water House Cooper, 2011; ICAI, 2013).

Two, in periods of cutbacks on exploration expenditure, a successful efforts method entity will ease off significant sums of expenses, usually arising from unsuccessful discoveries, from the statement of comprehensive income. In such a case, while the company's investment activities are reduced, the company's financial performance will show a rise in reported profit due to less expenditure being written off compared with previous years of reporting when operations were normal. This significant rise in profit will be felt for a year or two (Alfredson et al., 2009). This is because significantly less expense (dry holes costs) will be charged against revenues in the short-term, but for a medium to longer term, this would lead to lesser revenues due to contraction in exploration activities and production. The effects of cutting investments back on full cost companies are immaterial in the short-term compared to those of successful efforts. This is because the statement of comprehensive income of full cost companies will be refreshed by the cut into the DD\&A charges associated with the reduced exploration and evaluation expenditure, but this light effect will only be felt for a number of years to come. This is because reducing exploration activities and cutting exploration expenditure for full costing methods means less DD\&A charges being reported against revenues.

Finally, the profits of a company using successful efforts will be significantly reduced, or a loss may be reported, in a period when such a company may experience more unsuccessful operations due to writing off exploration expenditure. The effects of such a situation will be less detrimental on companies that use the full cost method of accounting due to the capitalization of these expenditures and spreading their negative effects over a number of years in the form of DD\&A charges to the statement of comprehensive income. It is argued that because the full cost method capitalizes every cost and depreciates, depletes and amortizes these costs using the same basis from year to year, a lesser distortion of the annual income will result compared to the successful efforts treatment of the unsuccessful expenditures (PwC, 2008; ICAI, 2013).

Given these many differences, several attempts to eliminate heterogeneous accounting practices by extractive industries have been made in order to provide a uniform accounting 
practice. Calls by the Financial Accounting Standard Board (FASB) have coalesced around solely favoring the successful efforts. However, due to strong lobbying by full costing companies, these calls have not been taken on board by the regulators (Flory and Grossman, 1978; Noël et al., 2010; Cortese, 2011). In fact, calls for the harmonization and restriction of the alternative accounting practices in the extractive industries go back to 1905 (Curle, 1905: 29, as cited in Corinne et al., 2009: 28). In 1908, the English Institution of Mining and Metallurgy established a Mine Account and Cost Sheets Committee to work toward a standard system for regulating the entire British mining industry (Luther, 1996:73). In 1977, Statement of Financial Accounting Standard (SFAS) No 19, issued by the FASB, called for the harmonization of oil and gas accounting and disclosing practices in a bid to reduce bias and improve comparability (Luther, 1996; Spear and Wise, 2002). An Issues Paper published by the International Accounting Standard Board (IASB) in 2000 retained the choice of accounting method. As such, debate rages among the extractive industries, the academic community and the accounting profession on the advantages and disadvantages of each of the accounting methods used by extractive industries. In 2004, the IASB issued IFRS 6, with an effective date of 1 January 2006, in order to provide an interim solution to the conflicting views associated with the two common methods of accounting for the activities of extractive industries. This paper assesses the effectiveness of IFRS 6 as a regulatory standard aimed at harmonizing the accounting treatments of extractive industries' expenditure.

\section{IFRS 6: Exploration for and Evaluation of Mineral Resources}

While the portion of E\&E expenditures incurred by entities engaged in extractive activities is significant, these expenditures are excluded from the scope of IAS 38: Intangible Assets, and mineral rights and non-regenerative resources are not covered by the IAS 16: Property Plant and Equipment (IFRS Foundation, 2010). This has led to diverse accounting treatments of these expenditures, which in turn has led to incomparable results reported by these entities. Therefore, the IASB issued the IFRS 6 to regulate and harmonize accounting practices for extractive industries.

The main objectives of IFRS 6 are to specify financial reporting for the E\&E of mineral resources. In particular, IFRS 6 requires the following:

“(a) limited improvements to existing accounting practices for exploration and evaluation expenditures. 
(b) Entities that recognise exploration and evaluation assets to assess such assets for impairment in accordance with this IFRS and measure any impairment in accordance with IAS 36 Impairment of Assets.

(c) Disclosures that identify and explain the amounts in the entity's financial statements arising from the exploration for and evaluation of mineral resources and help users of those financial statements understand the amount, timing and certainty of future cash flows from any exploration and evaluation assets recognised." (EN-EU IFRS 6, 2009).

Early evidence suggests that the first-time adoption of IFRS 6 had a significant impact on the reporting practices of companies, particularly in relation to the reporting of their opening net assets (see KPMG, 2007). This is because pre-IFRS 6, no uniform treatment for a number of exploration and evaluation costs existed across extractive companies. Companies had to apply their national Generally Accepted Accounting Principles (GAAP), which differs due to the diversity of accounting practices among countries (Roberts et al., 2008; Ernst \& Young, 2009).

Although IFRS 6 was issued as an accounting standard for the extractive industries, it only covers the recognition, measurement and reporting of expenditure in the E\&E phase of investment and, hence, does not include expenditures in either pre- or post-E\&E stages (Noël et al., 2010). The focus of the IFRS 6 on the E\&E stages is down to the significant expenditure incurred by extractive companies during these stages (IFRS Foundation, 2010). The application of IFRS 6 begins from the point where an entity has obtained legal rights to explore an area and ends with the establishment of commercially viable mineral resources, i.e., before the start of the development stage. This is the first sign of limitations of this standard. This is because extractive companies may use different accounting policies for preand post-E\&E expenditures leaving comparability of financial statements at a hard edge. Thus, it is evident that IFRS 6 only has a limited remit in terms of reducing the diversity in accounting practices amongst firms in the extractive industries, as it does not impact accounting and reporting matters associated with the other three investment stages (IFRS 6, 2013).

In terms of the accounting treatment of E\&E expenditures (including administrative and other general overhead costs), IFRS 6 requires that for each type of expenditure, an entity must adopt a clear policy of either immediate expensing or capitalization of these expenditures as an $\mathrm{E} \& \mathrm{E}$ asset. This is to reflect the extent to which each type of $\mathrm{E} \& \mathrm{E}$ expenditure relates to 
specific mineral resources. Hence, the requirements of IFRS 6 are seen to ally themselves more closely with the philosophy of the successful efforts method (see KPMG, 2005 \& 2007; Ernst \& Young, 2009). This requirement, while providing for some consistency of accounting treatments of similar expenditures in the same entity and hence providing a base for horizontal comparison, does not provide consistency in recognizing, measuring and reporting $\mathrm{E} \& \mathrm{E}$ expenses across the extractive industries. A concern is raised about linking $\mathrm{E} \& \mathrm{E}$ expenditure to the commerciality of mineral resources. This is because while in some cases E\&E expenditure can be linked directly to a successful discovery of mineral resources, which would then be capitalized, in other cases, E\&E expenditure may not be easily linked to certain mineral resources, such as research and development expenditure, and therefore would be expensed. Such a subjective evaluation in terms of linking E\&E expenditure to mineral resources aligns with the successful efforts method, which in turn may indicate a preference in IFRS 6 for successful efforts over the full cost method and, in fact, over other methods of accounting for extractive industries.

IFRS 6 defines activities prior to the acquisition of an exploration license as pre-E\&E. Because expenditure during the pre-E\&E activities cannot be assigned to specific mineral reserves, it should be expensed. This view aligns with the practice of the SE method. However, in some cases where pre-E\&E may give rise to an $E \& E$ asset, an entity may capitalize that expenditure if it meets the criteria of asset recognition.

IFRS 6 requires extractive companies to clearly classify E\&E assets into tangibles and intangibles. This classification is necessary for accounting policy choices related to the measurement of these assets after recognition and their disclosures (IFRS 6, 2013). The standard requires the classification and split of E\&E assets to be applied consistently. These assets are to be tested for impairment regularly, and the standard requires that entities apply IAS 36 (Impairment of Assets) to measure and report on the impairment of E\&E assets. In measuring E\&E assets after initial recognition, the standard permits companies to apply either the cost or the revaluation models in a consistent manner. By the same token, IFRS 6 requires entities to apply IAS 37 (Provisions, Contingent Liabilities and Contingent Assets) with regard to decommissioning costs that may incur as a result of undertaking E\&E activities.

Once the commercial viability of mineral resources is established, expenditure on development activities falls beyond the scope of IFRS 6. Therefore, extractive companies 
should determine an accounting policy to address these expenditures. Because development starts when commercial viability is established and future economic benefits are to be generated, development expenditures are normally capitalized by SE and FC companies alike.

In terms of accounting policy, IFRS 6 requires entities to determine their accounting policies based on the entity's current national GAAP. IFRS 6 permits an existing user to change its accounting policy only if the change makes its financial statements more reliable and no less relevant, or more relevant but no less reliable. However, because IFRS 6 does not contain specific requirements and criteria for changes in accounting policies, the requirements of IAS 8 (Accounting Policies, Change in Accounting Estimates and Errors) apply when such a change takes place (IFRS Foundation, 2010).

\section{Research Approach}

\subsection{Data Collection Method}

Content analysis is defined by Holsti (1969: 14), as cited in Bryman and Bell (2007: 302), as "any technique for making inferences by objectively and systematically identifying specific characteristics of messages". Content analysis can be used as a quantitative and/or a qualitative technique (Mayring, 2000) and can be in one of two forms: conceptual analysis (thematic analysis) or relational analysis. The objects of content analysis can be any sort of recorded communication, such as transcripts of interviews, mass media materials, companies' annul reports, letters, lecture notes, and newspaper articles (Mayring, 2000; Bryman and Bell 2007). Beardsowrth (1980), as cited in Bryman and Bell (2007: 303), states that content analysis focuses on, besides the linguistic structure of the text, themes within the text, which entails searching for certain ideas within the text. Based on this account, content analysis as a research method fits the purpose of our research. This is because our analysis of the accounting policies of oil and gas companies, incorporated in these companies' annual reports, besides being systematic, will emphasize the determination of whether these companies comply with the requirements of IFRS 6. In so doing, we are in fact applying the inductive approach, which moves from data collection and analysis to theory building (Saunders et al, 2003). Using the thematic analysis is considered most appropriate for this study. The themes that arises from the literature review, particularly from the description of the IFRS 6 requirements of extractive companies as presented in section 4 above, to be used 
in our analysis. These themes are: measurements of $E \& E$ assets, classifications of $E \& E$ assets, impairment assessment for E\&E assets and disclosure of E\&E assets. Furthermore, to assess compliance, or otherwise, of oil companies with the requirements of IFRS 6 a checklist of IFRS 6 required measurements and disclosures is created for this purpose. These requirements, or variable, in the checklist were developed based on the requirements of the IFRS 6. Appendix B includes a copy of the data collection checklist. On the checklist, each of the IFRS 6 requirements was coded as disclosed by the individual companies as (Yes) complied and/or (No) not complied. We checked statements of compliance in the companies' accounting policies, as per their annual reports, against companies' financial statements. This is to see if compliance with the IFRS 6 was in fact stated and applied by these companies. In fact, this is an analytical technique that was used by Street and Gray (2004). This investigation will address the extent to which the IFRS 6 has been a successful accounting standard, introduced by the IASB, in harmonizing accounting practices for the extractive industries.

\subsection{The Analysis}

The analysis is based on exploring the accounting policies and financial statements of a number of oil and gas companies as representatives of the extractive industries. The oil and gas industry is the largest among the extractive industries and has a significant visible political and economic role in both producing and consuming countries. The analysis will document the extent to which these companies have continued with their existing accounting policies and practices or amended them in line with the requirements of IFRS 6. Accounting policies of oil and gas companies usually clearly disclose how E\&E expenditure is accounted for; therefore our investigation will be directed mainly at checking whether E\&E expenditure is accounted for in accordance to IFRS 6 requirements or not. Our analysis will extend to check whether our sample companies adhere to the measurements and disclosure requirements of IFRS 6 and to the requirement of impairment of intangible assets tests.

\subsection{Sampling}

In checking the compliance of oil and gas exploration and production companies with IFRS 6, upstream oil and gas companies listed in major stock markets were searched, and a check list was developed for this purpose. Six major stock exchanges were identified for this purpose, these are: FTSE 350, Fortune, Toronto stock exchange, ISEQ, NYSE and Hang Seng. The choice of stock markets was based on the idea of having companies from around 
the world rather than focusing on one geographical area. In addition, these are the most active and largest stock exchanges, where oil and gas companies are more likely to list given the large financing requirements.

In defining our sample companies we first of all filtered the oil and gas companies in these stock markets, this was done by selecting the option of 'oil and gas producers' from a drop down menu of industry sector available on the stock markets' websites. Then we excluded any downstream oil and gas companies from our sample. Our focus is directed only on upstream oil and gas companies listed in these stock markets. Since the number of exploration and production oil and gas companies listed in these six stock markets is relatively small (27 companies) we extended our search to companies listed on the Alternative Investment Market (AIM). We checked the companies listed on the AIM on $14^{\text {th }}$ November 2014, using the sector company search option, and identified 108 oil and gas companies. From these 108 companies we excluded 12 companies that are not upstream oil and gas companies and we excluded one further company due to unavailability of this company's annual reports. This made our sample consists of 122 upstream oil and gas companies (see table 1). Accounting policies and financial statements of EVERY upstream oil and gas company listed on these stock markets was checked.

Annual reports and accounts of 122 exploration and production oil and gas companies listed on the above seven stock markets were used in the analysis. The analysis covers the period 2006 - 2014. Our sample companies were categorized according to their listing. Table A in the appendix provides summary information related to the sample companies; these information cover variables such as company domicile, area of operation, size of company and accounting method used.

\section{Analysis and Discussion}

\subsection{Descriptive Statistics}

Our initial analysis indicates that of the 122 sampled companies, $35(29 \%)$ use the full cost method of accounting, $57(47 \%)$ use the successful efforts method, of which at least 4 changed from full cost to successful efforts post 2004, 11 (9\%) use the area of interest method, and $19(16 \%)$ of the companies do not specify certain method. With regard to the adoption of certain accounting method, table 1 reveals the details. 
Table 1: Sample Companies

\begin{tabular}{|l|c|c|c|c|c|c|c|c|c|}
\hline \multicolumn{1}{|c|}{ Stock Market } & $\begin{array}{c}\text { FTSE } \\
350\end{array}$ & $\begin{array}{c}\text { Hang } \\
\text { Seng }\end{array}$ & NYSE & $\begin{array}{c}\text { Toronto } \\
\text { TSX }\end{array}$ & Fortune & ISEQ & AIM & $\begin{array}{c}\text { Total } \\
\text { Number of } \\
\text { Companies }\end{array}$ & $\%$ \\
\hline Successful Efforts & 12 & 3 & 2 & 0 & 0 & 2 & 38 & 57 & 47 \\
\hline Full Cost & 2 & 0 & 2 & 2 & 1 & 0 & 28 & 35 & 29 \\
\hline Area of Interests & 1 & 0 & 0 & 0 & 0 & 0 & 10 & 11 & 9 \\
\hline Not Clearly Stated & 0 & 0 & 0 & 0 & 0 & 0 & 19 & 19 & 16 \\
\hline $\begin{array}{l}\text { Number of } \\
\text { Companies }\end{array}$ & 15 & 3 & 4 & 2 & 1 & 2 & 95 & 122 & 100 \\
\hline
\end{tabular}

It is interesting to note that 19 companies, all from the AIM panel, do not disclose the adoption of certain accounting method, and 6 of the 11 area of interest companies are based in Australia. Also, whilst the 2 Toronto TSX companies follow the full cost method, the 3 Hang Seng and the 2 ISEQ companies follow the successful efforts method. The majority of the FTSE 350 companies follows the successful efforts method (12 companies) while 2 follows the full cost and 1 follows the area of interest.

\subsection{Compliance with IFRS 6 Requirements}

Compliance with the requirements of IFRS 6 measurement, classification of assets, impairment of E\&E assets and disclosure differs between companies in the different stock markets (see table 2). Whilst FTSE 350, Hang Seng and ISEQ companies adhere to the IFRS 6 requirements not every company from the other stock markets does so. It is worth mentioning that companies that do not follow IFRS 6 requirements use either full cost, area of interest, or not specified accounting method; successful efforts companies follow IFRS 6 requirements. 
Table 2: Compliance with IFRS 6 Requirements

\begin{tabular}{|c|c|c|c|c|c|c|c|c|c|c|}
\hline \multicolumn{2}{|c|}{ Stock Market } & \multirow{2}{*}{ FTSE 350} & \multirow{2}{*}{ Hang Seng } & \multirow{2}{*}{ NYSE } & \multirow{2}{*}{$\begin{array}{l}\text { Toronto } \\
\text { TSX }\end{array}$} & \multirow{2}{*}{ Fortune } & \multirow{2}{*}{ ISEQ } & \multirow{2}{*}{ AIM } & \multirow{2}{*}{ Totals } & \multirow{2}{*}{$\%$} \\
\hline \multicolumn{2}{|c|}{ Criteria } & & & & & & & & & \\
\hline \multirow{2}{*}{$\begin{array}{l}\text { Measurement } \\
\text { of E\&E Assets }\end{array}$} & Cost & 15 & 3 & 4 & 2 & 1 & 2 & 94 & 121 & 99 \\
\hline & Valuation & 0 & 0 & 0 & 0 & 0 & 0 & 1 & 1 & 1 \\
\hline \multirow{2}{*}{$\begin{array}{l}\text { Classification } \\
\text { of E\&E Assets } \\
\text { as Intangibles } \\
\text { and non- } \\
\text { Intangibles }\end{array}$} & YES & 15 & 3 & 2 & 1 & 0 & 2 & 85 & 108 & 89 \\
\hline & NO & 0 & 0 & 2 & 1 & 1 & 0 & 9 & 13 & 11 \\
\hline \multirow{2}{*}{$\begin{array}{l}\text { Impairment } \\
\text { Assessment } \\
\text { for E\&E } \\
\text { Assets }\end{array}$} & YES & 15 & 3 & 3 & 2 & 1 & 2 & 90 & 116 & 95 \\
\hline & NO & 0 & 0 & 1 & 0 & 0 & 0 & 5 & 6 & 5 \\
\hline \multirow{2}{*}{$\begin{array}{l}\text { Disclosure of } \\
\text { E\&E Assets }\end{array}$} & YES & 15 & 3 & 2 & 2 & 0 & 2 & 90 & 114 & 93 \\
\hline & NO & 0 & 0 & 2 & 0 & 1 & 0 & 5 & 8 & 7 \\
\hline \multicolumn{2}{|c|}{$\begin{array}{c}\text { Total Number of Companies } \\
\text { Researched }\end{array}$} & 15 & 3 & 4 & 2 & 1 & 2 & 95 & 122 & 100 \\
\hline
\end{tabular}




\subsection{Qualitative Analysis}

This section details the qualitative contain analysis of annual reports of the sample companies. It discusses level of compliance of a number of the sample companies to the requirements of IFRS 6; in so doing it provides evidences on compliance, or otherwise, of companies in our sample with the requirements of the IFRS 6.

Dana Petroleum (an AIM), a full cost method company, and BP (an FTSE 350), a successful efforts company both follow IFRS 6 disclosure requirements in that they classify the intangible assets into goodwill arising from the acquisition of subsidiaries and $E \& E$ assets. Furthermore, the capitalized E\&E assets are classified into intangible E\&E assets and tangible assets as Property, Plant and Equipment (PPE) (see annual reports and accounts of Dana Petroleum, 2011: 32 \& 51, and BP, 2011: 214). However, while Dana Petroleum separates its intangible assets into goodwill and E\&E assets, BP (in addition to identifying goodwill as a separate asset) classifies its intangible assets into $\mathrm{E} \& \mathrm{E}$ assets and other intangibles. On the other hand, other companies such as Anadarko (from the NYSE) and Lundin Petroleum (from the Toronto stock market) seem not to follow the IFRS 6 assets classification requirements.

Forum Energy is a UK based company listed on the AIM market and it has its major exploration and production activities in the Philippines. The company uses the full cost method in accounting for its oil and gas activities, however applies the IFRS 6 in accounting for its $\mathrm{E} \& \mathrm{E}$ assets. In this context the company states:

"Exploration, evaluation and development asset

The group applies the full cost method of accounting, having regard to the requirements of IFRS 6 "Exploration for and Evaluation of Mineral Resources". (Forum Energy, annual report: 27).

This in fact indicates that companies, driven by an institutional request, do adhere to the requirements of IFRS 6 and amend their accounting methods so they fulfill the guidance of the standard.

Salamander Energy, BP, BG Group, Enquest, Ophir Energy, JKX, Royal Dutch Shell Oil and Tullow (all from the FTSE 350 and AIM panel companies) disclosed that E\&E expenses are accounted for in accordance with the successful efforts method. This is in line with the guidance and requirements of the IFRS 6 (see for example Salamander Energy, 2012: 78; JKX, 2012: 115, Ophir Energy, 2012:83). These companies highlighted that they follow IFRS 
in preparing their accounts as a response to the European Union (EU) requirements of companies listed on EU stock markets to follow the IFRSs. This requirement of the EU is an essential driver for harmonizing accounting practice, and enforcing compliance with the IFRSs, among extractive companies listed in stock markets in the $\mathrm{EU}^{3}$ (Glaum et al., 2013). However, in some cases, companies, while indicating that they are adhering to the EU requirement in terms of using IFRS, do not adopt IFRS 6. This pool includes for example Chariot oil and gas, Eland oil and gas, Fastnet oil and gas, Frontera resources, and Westmount energy. For example, SOCO International, a full costing company, declared that it is adhering to IFRS in line with EU requirements; however, the company disclosed that they are utilizing full cost as a method for accounting for its investment expenditure, including E\&E expenditure (SOCO International plc, 2012: 74 \& 75). It is interesting to note that SOCO International plc applied IFRS 6 to new E\&E expenditure, where there was no existing established cost pool. In this regard, the company disclosed that:

"Intangible acquisition, exploration and evaluation costs incurred in a geographical area where the Group has no established cost pool are initially capitalised as intangible non-current assets except where they fall outside the scope of IFRS 6 Exploration for and Evaluation of Mineral Resources whereby they are expensed as incurred subject to other guidance under IFRS.” (SOCO International plc, 2012: 75).

This practice of SOCO International indicates that the company is in fact converting its accounting treatments to comply with the requirements of IFRS 6; this applies to newly explored oil and gas reserves, where no cost pools have yet been established. In the longer term, this leads to SOCO International and similar companies adopting IFRS 6 in accounting for their entire E\&E expenditure. Although the number of this type of companies is small, at least in our sample, the practice indicates that IFRS 6 is making progress in harmonizing accounting practices for this type of company to align with SE companies.

Apache Corporation, an NYSE company, and Devon Corporation, a Canadian Fortune panel company, both well-established exploration and production oil and gas firms, follow the full cost methods in accounting for their operations. The companies' accounting policies state that E\&E expenditure is capitalized in accordance with the full cost method of accounting. Hence, these companies, while not required to employ IFRS 6 guidance and instructions to capitalize

\footnotetext{
${ }^{3}$ On 19 July 2002, a regulation was passed by the European Parliament and the European Council of Ministers requiring the adoption of IFRS: Regulation (EC)No 1606/2002 of the European Parliament and of the Council of 19 July 2002 on the application of international accounting standards. As a result of the Regulation, all EU listed companies were required to prepare their financial statements following IFRS from 2005 (ICAEW, 2014: online).
} 
E\&E expenditure that can be related to a successful discovery, in fact follow the general guidance of the standard. IFRS 6: 6-7 states that an entity can either develop or continue applying a policy that expenses or capitalizes E\&E expenditure in accordance with what the management deems most appropriate in providing relevant and reliable information. Extractive companies that use the full costing method of accounting may elect not to follow the IFRS 6 guidance, as the change in the accounting treatment of their E\&E expenditure may have an adverse effect on their financial statements. This adverse effect is due to the need to write off significant sums (related to unsuccessful discoveries) that were previously capitalized in their income statements, thus affecting their share prices. In such cases, the IFRS 6 is, in fact, not playing an effective role in harmonizing the accounting treatments of E\&E expenditures incurred by extractive companies but in reality, as Cortese and Irvine (2010) suggested, codifies existing accounting practices by extractive companies.

Heritage Oil company is incorporated in Jersey and is listed on both the London Stock Exchange (LSE) and the Toronto Stock Exchange (TSX). The company has exploration and production activities in Russia, Africa and the Middle East. Exploration and evaluation assets are classified separately from other assets, and these are subject to impairment tests. The company uses a modified full costing method, as reported by the company's accounting policy (see quote below) to account for its exploration and evaluation expenditure. This is done to comply with the requirements of IFRS 6 and to adhere to the EU requirements of adopting IFRSs by corporations listed in the EU zone (Heritage, 2012, annual report: 16). In this regard, the annual report of Heritage Oil, in the financial statement section, states:

"The Group applies a modified full cost method of accounting for exploration and evaluation ("E\&E") costs, having regard to the requirements of IFRS 6 Exploration for and Evaluation of Mineral Resources. Under the modified full cost method of accounting, costs of exploring for and evaluating oil and gas properties are capitalised on a license or prospect basis and the resulting assets are tested for impairment by reference to appropriate cost pools. Such cost pools are based on geographic areas and are not larger than a segment." (Heritage Oil, 2012, annual report: 17)

In fact, Heritage Oil is not the only company that applies a modified full cost accounting method; Cadogan Petroleum Plc applies the same principal as Heritage oil (see Cadogan Petroleum Plc, 2013, annual report: 50).

Ascent Resources Plc, an AIM successful efforts company and based in London, demonstrates its compliance with IFRS 6 with regard to impairment of its intangible assets. In this context Ascent Resources Plc states in its 2011 annual report (p. 45) the following: 


\section{"Impairment of oil and gas exploration assets}

Exploration/appraisal assets are reviewed regularly for indicators of impairment following the guidance in IFRS 6 'Exploration for and Evaluation of Mineral Resources' and tested for impairment where such indicators exist. Any impairment arising is recognised in the Income Statement for the year."

Husky Energy, a full cost company based in Canada and listed on the Toronto Stock Exchange, indicated in its 2010 annual report (p. 58) its transition to IFRS:

"The Company is progressing in its IFRS transition project in preparation for timely completion of the first IFRS interim financial report in the first quarter of 2011.”

However, the 2013 annual report of Husky Energy states:

"The Company employs the full cost method of accounting for oil and gas interests whereby all costs of acquisition, exploration for and development of oil and gas reserves are capitalized and accumulated within cost centers on a country-by-country basis. Such costs include land acquisition, geological and geophysical activity, drilling of productive and non-productive wells, carrying costs directly related to unproved properties and administrative costs directly related to exploration and development activities." (Husky Energy, 2013, annual report: 77)

Although the company's 2010 annual report made it clear that they intended to make a transition to the IFRSs, the company seemed not to have made the transition yet by the end of 2013. The intention of the transition to applying IFRSs, and hence IFRS 6, may be considered a sign of future success of the standard in its objective of harmonizing accounting practices for the extractive industries. However, this transition into applying IFRS is based on a CICA Accounting Standard Board (AcSB) that required Canadian publicly accountable companies to adopt International Financial Reporting Standards (IFRS) for fiscal periods beginning 1 January 2011 (Huskey Energy, 2010, annual report: 58).

The Hang Seng panel companies contains three companies: Petro China, Sinopec Corp and CNOOC. All three companies use the successful efforts method to account for their operations and, therefore, to comply with the requirements of IFRS 6 . This is not a surprising result, as Chinese companies have been required to adopt China Accounting Standards (CAS) since 2006, and these standards are in fact based on and generally consistent with the IFRSs (IFRS, 2014). Further, Street and Gray (2004) report that Chinese listed companies have high levels of compliance with international accounting standards. 
Using the same approach, we checked companies listed on the NYSE and we found evidence that some companies do use the full costing method and do not adhere to the requirements of IFRS 6. For example, American Eagle Energy Corporation states in their annual report:

"The Company follows the full-cost method of accounting for its investments in oil and gas properties. Under the full-cost method, all costs associated with the acquisition, exploration or development of properties, are capitalized into appropriate cost centers within the full-cost pool. Internal costs that are capitalized are limited to those costs that can be directly identified with acquisition, exploration, and development activities undertaken and do not include any costs related to production, general corporate overhead, or similar activities. Cost centres are established on a country-by-country basis.” (American Eagle Energy Corporation, 2013, annual report: 41)

The above statement clearly indicates that American Eagle Energy Corporation, and similarly Apache Corporation and to some extent Anadarko, does not attend to the requirements of IFRS 6. This seems to be the norm for American companies that follow their national GAAP in their accounting practices but not the international accounting standards. In fact, under US GAAP, oil and gas companies may use full costing or successful efforts methods to account for their expenditure (Ernst \& Young, 2009). In our view, this practice by American companies limits the success of IFRS 6. However, it is relevant to mention here that the SEC has issued a roadmap for the potential use of IFRS by US companies. This roadmap may, in the future, lead to US companies being required to adopt IFRSs if the SEC believes it is in the public interest (IFRS, 2014: online).

In the same line of argument, it is worth noting that in some cases companies indicated that they changed their accounting method from full cost to successful efforts, not as a response to the requirements of IFRS 6, but for other reasons. In this context, Cheniere Energy, a company listed on the NYSE, changed its accounting method from full costing to successful efforts in effect from 1 January 2006. The change came as a response to Statement of Financial Accounting Standards (SFAS) number 154. The effects of this change were described by the company as follows:

"The cumulative effect of the change in accounting method as of December 31, 2005 and 2004 was to reduce the balance of our net investment in oil and gas properties and retained earnings at those dates by $\$ 18.0$ million and $\$ 18.2$ million, respectively. The change in accounting method resulted in a decrease in the net loss of $\$ 0.3$ million and an increase in the net loss of $\$ 0.3$ million for the years ended December 31, 2005 and 2004, respectively, and had no impact on earnings per share (basic and diluted) for these respective periods (see Note 16-“'Adjustment to Financial StatementsSuccessful Efforts" of our Notes to Consolidated Financial Statements). The change 
in method of accounting had no impact on cash or working capital" (Cheniere Energy, 2006:67).

Cheniere Energy's annual report indicated that it has a small proportion of its investment activities in exploration for and production of oil and gas, while the majority of its investment focuses on downstream activities. This could explain the slight negative effect on its reported figures of changing its accounting method. However, the financial statements of companies with larger extractive investment activities would be affected more severely than those of Cheniere Energy's extent of upstream oil and gas activities if such a change in accounting method occurred.

Good examples of disclosures focusing on the change in accounting method from a full cost approach to the successful efforts method as a response to IFRS 6 were offered by Premier Oil and Cairn Energy from FTSE 350 panel companies and Petroceltic plc (formally Melrose Resources) from AIM group, All three companies changed their accounting method from full cost to successful efforts in 2005. This change had a significant impact on their financial statements. For example, changing from full cost to successful efforts resulted in Premier Oil charging US\$38.5 million to the income statement. However, the change gave the company some financial relief on tax and other payments (Premier Oil, 2005, annual report: 61). The company has made it clear that the successful efforts methods is used to account for E\&E expenditure in accordance with the requirements of IFRS 6 (Premier oil, 2012, annual report: 83). With regard to Cairn Energy, $£ 63$ million of unsuccessful exploration and appraisal costs were written off as a consequence of changing the accounting policy, and the net assets of the company were reduced by $£ 82$ million (KPMG, 2007: 5; Cairn Energy, 2005, annual report). In the same vein, the net assets of Melrose Resources were reduced by US\$24 million due to their change in accounting policy (Melrose Resources, 2005, annual report).

Another stream of companies seems not to state their accounting method clearly, however they still follow the requirements of IFRS 6 in accounting for their E\&E expenditure. The bulk of these companies found in the AIM panel (see table 1). In this regard, for example Serica Energy states in their 2013 (p, 33) annual report

"Exploration and Evaluation Assets as allowed under IFRS 6 and in accordance with clarification issued by the International Financial Reporting Interpretations Committee, the Group has continued to apply its existing accounting policy to exploration and evaluation activity, subject to the specific requirements of IFRS 6. 
The Group will continue to monitor the application of these policies in light of expected future guidance on accounting for oil and gas activities."

Following the investigation of the accounting practices of the 122 sampled companies based on the requirements of the IFRS 6, seven categories of companies were identified:

1. Companies that already comply with the requirements of IFRS 6 and use the successful efforts method in accounting for their entire operations;

2. Companies that follow the full cost method, or methods other than SE, and do not adopt IFRS 6 for accounting for their E\&E expenditure;

3. Companies that follow the full cost method of accounting but adopted IFRS 6 to account for E\&E expenditure;

4. Companies that changed their accounting policies post-2004 from full cost to successful efforts but for reasons other than compliance with IFRS 6;

5. Companies that changed their accounting method from full cost to successful efforts merely to be aligned with the requirements of IFRS 6; and

6. Companies using the full cost method but applying IFRS 6 for new E\&E properties where there is no existing cost pool in the area of new discoveries.

7. Companies that do not disclose certain accounting method but follow the requirements of IFRS 6.

\section{Conceptualizing Different Forms of Accounting in the Extractive Industries}

Investments in extractive industries is carried out over a number of distinctive stages: acquisition, exploration, evaluation, development and production. Accounting for extractive industries expenditure is undertaken by different methods: successful efforts, full costing, area of interests, appropriation and reserve recognition accounting. The "telling it like it is" is different for each of these methods from the other methods and each of these methods leads into incomparable results with the other methods. For example, balance sheets of full costing methods will witness a buildup of fixed assets from year to year on a faster scale compared to successful efforts companies. Profits reported by full costing companies is higher when compared to that of a successful efforts companies on the earning per share basis. These differences do not address the "decision-making" aid criterion that is expected from accounting as two companies in the same sector, of the same size, and of a similar operations 
would have two different performance figures if one of them uses the full costing method and the other uses the successful efforts method. Therefore, there has been a need for generally accepted accounting standard that besides providing transparency and comparability bridges the gaps in between the different accounting methods. Furthermore, this standards needed to provide a blanket guidance that, when followed by extractive industries, harmonize accounting practice among different extractive companies and makes the "decision-making" criterion feasible. This is essentially to serve the world capital markets and other stakeholders. Here comes the IFRS 6 as a crucial attempt by the IASB to harmonize accounting practice among extractive companies. The objectives of this standard, although being squeezed in the E\&E stages of investments, have focused on a number of key areas within the E\&E stages: measurements, impairment, classification and disclosure. As has been illustrated in the literature, the political lobbying of extractive companies and the resistance of a number of corrupted mineral resources rich governments limited the scope of IFRS $6 .{ }^{4}$ However, as the IFRS 6 has been introduced and being applied by a number of companies that gives a hope that its scope may be widened in future and more companies would adopt it for their accounting practices.

This conceptualization view is represented in Figure 1 below.

\footnotetext{
${ }^{4}$ Due to political and economic corruption a number of governments of mineral resources rich countries prohibit transparent disclosure of mineral operations and reserves. This allows extractive companies to escape tax payments and corrupted government to hid part of their wealth from their people (Gallhofer and Haslam, 2007)
} 
Figure 1: Conceptualization of Different Accounting Methods in the Extractive Industries

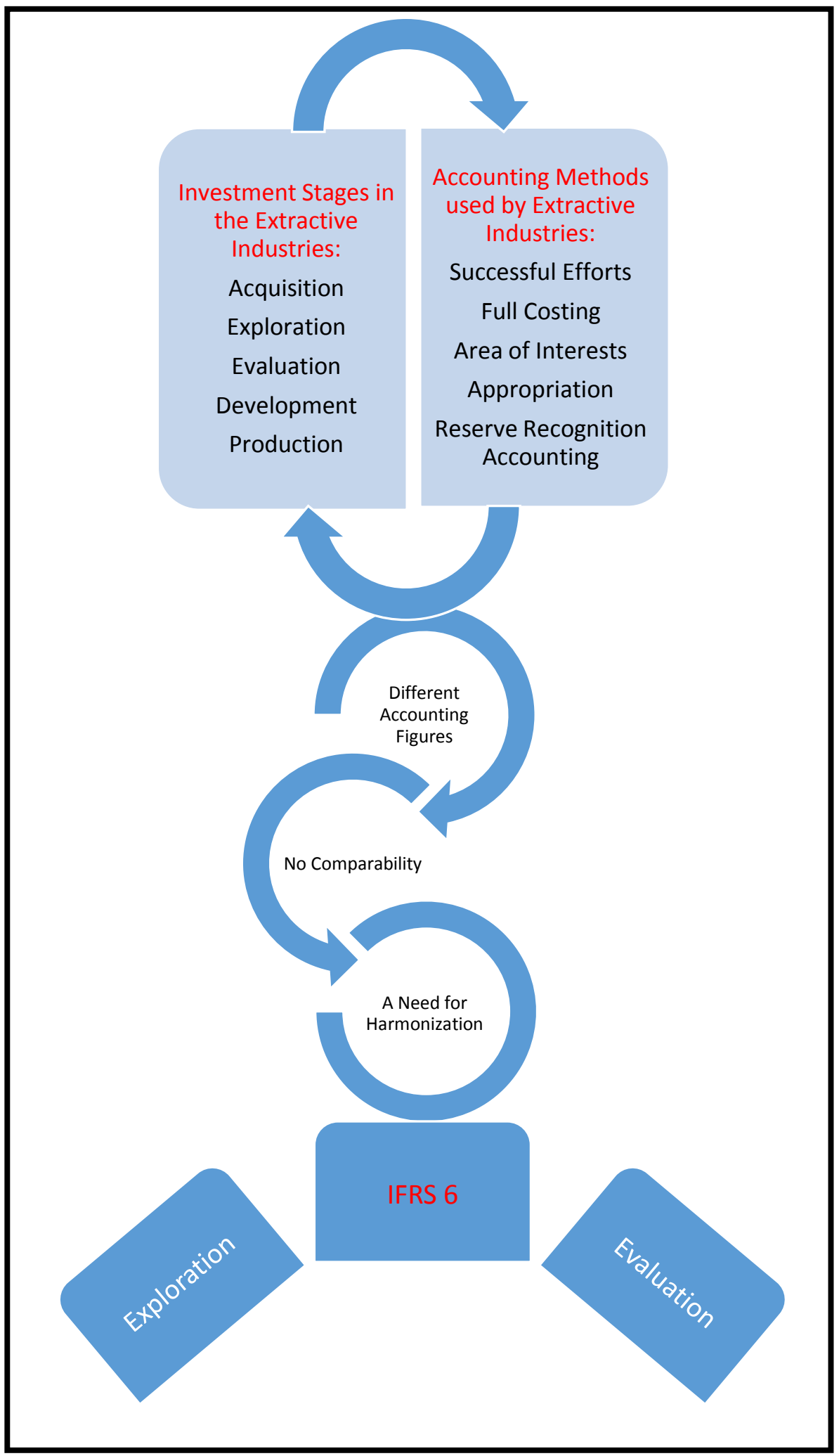




\section{Conclusion}

The analysis shows that extractive companies have responded differently to the requirements of IFRS 6. While some companies elected to change their accounting method from full cost to successful efforts as a response to the requirements of the standard, other companies chose to continue with their accounting policies and to use the full cost method to account for their E\&E expenditure. Even those companies that continued with their existing accounting method but elected to adopt IFRS 6 had to change certain accounting policies in accordance with the requirements of IFRS 6.

The evidence suggests that IFRS 6 has made a positive impact toward harmonizing accounting practices in the extractive industries, as a number of companies comply with the guidance of the standard. This should ensure greater comparability of reported information for the stakeholders of these industries. However, the success of IFRS 6 in harmonizing accounting practices for extractive industries is limited, as a number of companies opted not to follow the standard, as IFRS 6 did not enforce changes of accounting treatments for E\&E expenditure but only suggested that companies adopt the right method to suit their purposes as far as providing relevant and reliable information disclosed to stakeholders.

Meeting the objectives of IFRS 6 can be driven by a number of factors. Institutional interventions in the accounting practices of extractive industries have a significant enforcement effect in providing for a uniform application of international accounting standards and, hence, in harmonizing accounting practices amongst firms in the extractive industries sector. In this context, the move to IFRS has been a key driver for companies listed on regulated markets in the EU to adopt IFRS 6. This adoption in itself is a measure of the success of the standard in terms of harmonizing accounting practices among extractive industries in the EU. In other words, a wider acceptance of and compliance with the IFRS 6 seem to be driven by a successful enforcement of the standard; a result that is consistent with Street and Gray (2004) and with Glaum et al (2013). In this regard, Glaum et al (2013) state that national laws, capital market regulations, governance structure and other institution interventions enforces adherence to reporting standards. The institutional intervention has defended Cortese et al (2010) point that the IFRS 6 has codified companies' practices, this is initially because this intervention did not allow a codifying practice to take place but rather 
unified that practice. Willingness of extractive companies to aid the "decision-making" requirements by stakeholders and to serve the world capital markets by providing comparable information for investment decisions.

However, Implementation of IFRS 6 faces a number of challenges, first, the political lobbying of extractive companies and the resistance of a number of corrupted mineral resources rich governments limited the scope of IFRS $6 .^{5}$ It is well recognized that the extractive industry sector consists of a number of financially strong companies that have the power to lobby against proposed changes should those changes not be in their interests. The accounting method favored by these companies would be the one that produces the most favorable results for them. Smaller and pre-mature companies prefer full cost methods, and larger and well-established companies prefer the successful efforts method. Second, changing accounting methods for established extractive companies comes at significant costs. Those companies that changed their accounting method have been subject to a significant financial impact in terms of their opening net asset values. Third, some countries, such the USA, require their companies to adopt their national GAAP, which may not be aligned with IFRSs, thus impeding the goals of IFRSs. IFRS 6, in its current form, lacks a strong message that extractive industries should use one common accounting method for their operations.

After almost eight years since it was first implemented the IFRS 6 seems not to have met the complete desire for a comprehensive harmonized accounting practice among extractive companies it does in fact make a positive impact in this regard. The IASB needs to revisit the IFRS 6 and possibly extend its scope to cover pre-exploration expenditures. In addition, there needs to be more institutional pressure on extractive companies to adopt and apply the IFRS 6.

An overall conclusion can be drawn on the success of the IFRS 6 in harmonizing accounting practices among firms in the extractive industries sector. Although there seems to be seven different categories of companies that differ in terms of their compliance with the IFRS 6 , it can be said that the standard has been a key factor in providing for some degree of harmonization in the accounting practices of firms in the extractive industries sector. This is evident in the adoption by many companies of IFRS 6 for recording their E\&E exploration costs. However, it cannot be claimed that the IFRS 6 has witnessed complete success in this

\footnotetext{
${ }^{5}$ Due to political and economic corruption a number of governments of mineral resources rich countries prohibit transparent disclosure of mineral operations and reserves. This allows extractive companies to escape tax payments and corrupted government to hid part of their wealth from their people (Gallhofer and Haslam, 2007)
} 
area, a number of companies in our sample, although adopting IFRS 6, do not fully comply with its requirements and a number of other companies do not comply with its requirements at all.

Further exploration of the disclosures made by firms in the extractive industries, other than the oil and gas industry, is needed to allow for a stronger generalization to be made. In addition, a more detailed analysis of the information provided by these firms would yield more robust results and allow more definitive claims to be made about the state of reporting among firms in the extractive industries sector post-IFRS 6. The results of this study should be of interest to extractive companies, professional accounting bodies and other stakeholders. 
Appendix

\section{Table A: Sample Companies and Accounting Methods Adopted}

\begin{tabular}{|c|c|c|c|c|c|c|}
\hline Company & Listing & Base & Areas of Operation & $\begin{array}{r}\text { Total Assets } \\
\text { ('000) }\end{array}$ & Revenue ('000) & Accounting Method \\
\hline \multicolumn{7}{|c|}{ Panel A: AIM Companies } \\
\hline 3 Legs Resources plc & AIM & Isle of Man & Poland; Germany & $£ 58,252$ & 0 & Full Cost \\
\hline $\begin{array}{l}\text { Amerisur Resources } \\
\text { plc }\end{array}$ & AIM & Wales / UK & Paraguay; Colombia & US\$152,922 & US $\$ 42,190$ & Successful Efforts \\
\hline Andes Energia Plc & AIM & London / UK & $\begin{array}{c}\text { Argentina, } \\
\text { Colombia, Brazil and } \\
\text { Paraguay }\end{array}$ & US $\$ 22,456$ & US\$24,549 & Successful Efforts \\
\hline Antrim Energy & AIM & Canada & UK and Ireland & US\$ 91,836 & US\$ Zero & Successful Efforts \\
\hline Argos Resources & AIM & Falkland Islands & Falkland Islands & US $\$ 32,024$ & US\$ Loss & Full Cost \\
\hline Ascent Resources plc & AIM & London / UK & $\begin{array}{c}\text { Hungary; } \\
\text { Netherlands; } \\
\text { Switzerland; } \\
\text { Slovenia; Italy }\end{array}$ & $£ 36,888$ & $£ 1,684$ & Successful Efforts \\
\hline Azonto Petroleum & AIM & London / UK & $\begin{array}{l}\text { West Africa; } \\
\text { Australia }\end{array}$ & US\$59,173 & US\$519 & Area of Interest \\
\hline $\begin{array}{l}\text { Bahamas Petroleum } \\
\text { Company plc }\end{array}$ & AIM & Isle of Man & Bahamas & US\$68,413 & N/A & Area of Interest \\
\hline Bankers Petroleum & AIM & Albania & Albania & US $\$ 1,007,148$ & US $\$ 466,639$ & Full Cost \\
\hline Baron Oil Plc & AIM & London / UK & Latin America & $£ 12,402$ & $£ 2,211$ & Successful Efforts \\
\hline $\begin{array}{l}\text { Borders \& Southern } \\
\text { Petroleum plc }\end{array}$ & AIM & London / UK & Falkland Islands & US\$316,011 & N/A & Full Cost \\
\hline BowLeven plc & AIM & Edinburgh / UK & Cameroon; Kenya & US\$588,006 & 0 & Successful Efforts \\
\hline $\begin{array}{l}\text { Cadogan Petroleum } \\
\text { plc }\end{array}$ & AIM & London / UK & Ukraine & US\$207,976 & US\$5,653 & Full Cost \\
\hline Caza oil and Gas & AIM & USA & USA & US\$79,100 & US $\$ 8,312$ & Not Clearly Stated \\
\hline Chariot Oil and Gas & AIM & London / UK & $\begin{array}{l}\text { South America and } \\
\text { North Africa }\end{array}$ & US\$194,429 & US\$(10,455) & Full Cost \\
\hline Circle Oil plc & AIM & Ireland & $\begin{array}{l}\text { Morocco; Tunisia; } \\
\text { Oman; Egypt }\end{array}$ & US\$260,913 & US\$73,270 & Full Cost \\
\hline Clontarf Energy plc & AIM & Ireland & $\begin{array}{c}\text { Africa; South } \\
\text { America }\end{array}$ & $£ 5,324$ & 0 & Successful Efforts \\
\hline Dana Petroleum plc & AIM & Aberdeen / UK & $\begin{array}{l}\text { North Sea; Kenya; } \\
\text { Australia }\end{array}$ & $£ 2,885,594$ & $£ 1,091,658$ & Full Cost \\
\hline Desire Petroleum plc & AIM & $\begin{array}{c}\text { Worcestershire / } \\
\text { UK }\end{array}$ & Falkland Islands & US\$11,060 & 0 & Successful Efforts \\
\hline
\end{tabular}




\begin{tabular}{|c|c|c|c|c|c|c|}
\hline Egdon Resources plc & AIM & Hampshire / UK & UK; France & $£ 20,476$ & $£ 2,614$ & Full Cost \\
\hline Eland Oil and Gas & AIM & Aberdeen / UK & West Africa & US\$183,163 & $\mathrm{US} \$(26,142)$ & Not Clearly Stated \\
\hline Enegi Oil & AIM & Manchester/ UK & Canada, Ireland, UK & $£ 8,035$ & $£ 184$ & Not Clearly Stated \\
\hline $\begin{array}{l}\text { Empyrean Energy } \\
\text { plc }\end{array}$ & AIM & London / UK & US & $£ 15,245$ & $£ 2,694$ & Area of Interest \\
\hline Energy XXI & AIM & Houston / USA & US & US\$7,436 & US $\$ 1,230$ & Full Cost \\
\hline $\begin{array}{l}\text { Europa Oil \& Gas } \\
\text { plc }\end{array}$ & AIM & London / UK & Ireland; France & $£ 8,974$ & $£ 5,080$ & Full Cost \\
\hline Falcon Oil and Gas & AIM & Dublin / Ireland & $\begin{array}{c}\text { East Europe, Africa } \\
\text { and Australia }\end{array}$ & US\$89,516 & US $\$(3,570)$ & Full Cost \\
\hline Falkland Oil and Gas & AIM & London / UK & Falkland Islands & US\$372,486 & US\$(4,005) & Full Cost \\
\hline Faroe Petroleum plc & AIM & Aberdeen/ UK & North Sea; Norway & $£ 460,887$ & $£ 158,792$ & Full Cost \\
\hline Fastnet Oil and Gas & AIM & Stockport / UK & Morocco and Ireland & US\$69,162 & US\$2,557 & Not Clearly Stated \\
\hline Forum Energy plc & AIM & Surrey / UK & Philippines & US\$43,347 & US $\$ 4,522$ & Full Cost \\
\hline Frontera Resources & AIM & Texas USA & $\begin{array}{l}\text { Azerbaijan and } \\
\text { Georgia }\end{array}$ & US\$17,018 & US\$6,054 & Full Cost \\
\hline $\begin{array}{l}\text { Global Petroleum } \\
\text { Ltd }\end{array}$ & $\begin{array}{l}\text { AIM } \\
\text { (and } \\
\text { ASX) }\end{array}$ & Australia & Africa (Namibia, & US\$18,301 & US\$395 & Area of Interest \\
\hline Gulfsands Petroleum & AIM & UK & $\begin{array}{l}\text { Middle East and } \\
\text { North Africa } \\
\text { (MENA) }\end{array}$ & US $\$ 211,202$ & US $\$ 4,367$ & Successful Efforts \\
\hline Hurrican Energy & AIM & Surry / UK & $\begin{array}{l}\text { UK Continental } \\
\text { Shelf }\end{array}$ & $£ 179,406$ & $£ 125$ & Successful Efforts \\
\hline IGas Energy & AIM & London / UK & $\begin{array}{l}\text { UK Continental } \\
\text { Shelf }\end{array}$ & $£ 41,048$ & $£ 75,917$ & Successful Efforts \\
\hline $\begin{array}{l}\text { Independent } \\
\text { Resources }\end{array}$ & AIM & London/ UK & North Africa & $£ 1,127$ & $£ 704$ & Not Clearly Stated \\
\hline $\begin{array}{l}\text { Independent Oil and } \\
\text { Gas }\end{array}$ & AIM & London /UK & $\begin{array}{l}\text { UK Continental } \\
\text { Shelf }\end{array}$ & $£ 16,495$ & $£(856)$ & Successful Efforts \\
\hline Indus Gas Ltd & AIM & Guernsey/UK & Rajasthan and India & US\$427,868 & US\$27,834 & Full Cost \\
\hline InfraStrata Plc & AIM & Surry / UK & $\begin{array}{l}\text { UK Continental } \\
\text { Shelf }\end{array}$ & $£ 1,793$ & $£ 17,764$ & Full Cost \\
\hline Ithaca Energy Ltd & AIM & Aberdeen / UK & $\begin{array}{l}\text { UK Continental } \\
\text { Shelf }\end{array}$ & US\$2,618,904 & US\$90,094 & Not Clearly Stated \\
\hline Jubilant Energy & AIM & The Netherlands & India & US\$543,697 & US\$17,007 & Not Clearly Stated \\
\hline Jupiter Energy Ltd & AIM & Australia & Kazakhstan & $\mathrm{A} \$ 2,900$ & $\mathrm{~A} \$ 7,586$ & Area of Interest \\
\hline KEA Petroleum Plc & AIM & London / UK & New Zealand & $£ 23,753$ & $£ 829$ & Full Cost \\
\hline $\begin{array}{l}\text { Lansdowne Oil and } \\
\text { Gas }\end{array}$ & AIM & Dublin / Ireland & Ireland & $£ 29,842$ & $£(810)$ & Successful Efforts \\
\hline
\end{tabular}




\begin{tabular}{|c|c|c|c|c|c|c|}
\hline LekOil & AIM & USA & Africa & US\$169,712 & US\$18,112 & Full Cost \\
\hline Leyshon Energy & AIM & Beijing / China & China & US\$7,069 & US $\$(8,896)$ & Successful Efforts \\
\hline LGO Energy Plc & AIM & London / UK & Trinidad, Spain & $£ 23,192$ & $£ 5,913$ & Successful Efforts \\
\hline Madagascar Oil & AIM & $\begin{array}{l}\text { Madagascar / } \\
\text { Africa }\end{array}$ & Madagascar / Africa & US\$247,570 & US\$(12,092) & Full Cost \\
\hline Magnolia Petroleum & AIM & USA & USA & US\$16,149 & US $\$ 2,443$ & Successful Efforts \\
\hline Maple Energy & AIM & Dublin / Ireland & Peru / Latin America & US\$326,138 & US $\$ 133,312$ & Successful Efforts \\
\hline Max Petroleum & AIM & London / UK & Kazakhstan & US\$271,850 & US\$100,430 & Successful Efforts \\
\hline Mercom Oil Sands & AIM & London /UK & Alberta /Canada & $£ 2,024$ & $£(694)$ & Not Clearly Stated \\
\hline Mosman Oil and Gas & AIM & Perth / Australia & $\begin{array}{c}\text { Australia and New } \\
\text { Zealand }\end{array}$ & $\mathrm{A} \$ 10,546$ & $\mathrm{~A} \$(1,863)$ & Area of Interest \\
\hline New World Oil & Aim & Jersey / Australia & Denmark & $\mathrm{A} \$ 15,076$ & $\mathrm{~A} \$(11,945)$ & Not Clearly Stated \\
\hline $\begin{array}{l}\text { Nighthawk Energy } \\
\text { Plc }\end{array}$ & AIM & London /UK & Colorado / US & US\$96,419 & US\$26,154 & Successful Efforts \\
\hline Northcot Energy & AIM & $\begin{array}{l}\text { British Virgin } \\
\text { Islands / UK }\end{array}$ & US & US $\$ 8,664$ & US\$989 & Full Cost \\
\hline Northern Petroleum & AIM & London / UK & $\begin{array}{c}\text { Italy, Canada, UK, } \\
\text { Australia }\end{array}$ & $€ 81,343$ & $€ 593$ & Full Cost \\
\hline $\begin{array}{l}\text { Nostra Terra Oil and } \\
\text { Gas }\end{array}$ & AIM & London /UK & US & $£ 4,341$ & $£ 851$ & Successful Efforts \\
\hline Oilex Petroleum & AIM & Australia & India, Australia & US\$39,577 & US\$250 & Successful Efforts \\
\hline $\begin{array}{l}\text { Pantheon Resources } \\
\text { Plc }\end{array}$ & AIM & London / UK & US & $£ 4,216$ & $£ 5$ & Successful Efforts \\
\hline Parkmead Group Plc & AIM & Aberdeen / UK & UK, Netherlands & $£ 127,444$ & $£ 24,656$ & Not Clearly Stated \\
\hline Petrel Resources & AIM & Dublin / Ireland & $\begin{array}{c}\text { Ireland, Iraq and } \\
\text { Ghana }\end{array}$ & $€ 9,688$ & $€ 745$ & Not Clearly Stated \\
\hline Petro Matad Ltd & AIM & $\begin{array}{c}\text { Douglas / Isle of } \\
\text { Man }\end{array}$ & Mongolia & US\$19,995 & US\$188 & Area of Interest \\
\hline $\begin{array}{l}\text { Petroceltic plc } \\
\text { (formerly Melrose) }\end{array}$ & $\begin{array}{l}\text { AIM, } \\
\text { ISEQ }\end{array}$ & Dublin / Ireland & $\begin{array}{l}\text { Egypt; Bulgaria; US; } \\
\text { France; Turkey }\end{array}$ & US\$946,029 & US\$59,435 & $\begin{array}{c}\text { Full Cost pre } 2005 \\
\text { Successful Efforts post } \\
2005\end{array}$ \\
\hline $\begin{array}{l}\text { PetroNeft Resources } \\
\text { Ltd }\end{array}$ & $\begin{array}{l}\text { AIM } \\
\text { ESM }\end{array}$ & Dublin / Ireland & Russia & US\$132,558 & US\$38,687 & Successful Efforts \\
\hline President Energy Plc & AIM & London / UK & $\begin{array}{c}\text { South America, } \\
\text { Australia }\end{array}$ & US\$111,312 & US\$13,408 & Successful Efforts \\
\hline $\begin{array}{l}\text { Providence } \\
\text { Resources }\end{array}$ & AIM & Dublin / Ireland & Ireland; UK & $€ 92,013$ & $€ 2,797$ & Full Cost \\
\hline Range Resources & AIM & Perth / Australia & $\begin{array}{l}\text { Trinidad; Guatemala; } \\
\text { Georgia, Puntland; } \\
\text { Columbia }\end{array}$ & US\$166,157 & US\$21,185 & Area o of Interest \\
\hline
\end{tabular}




\begin{tabular}{|c|c|c|c|c|c|c|}
\hline $\begin{array}{l}\text { Red Emperor } \\
\text { Resources }\end{array}$ & $\begin{array}{l}\text { AIM } \\
\text { ASX }\end{array}$ & Perth / Australia & $\begin{array}{c}\text { Puntland; Somalia; } \\
\text { Georgia }\end{array}$ & US\$32,602 & US\$422 & Area of Interest \\
\hline Regal Petroleum & AIM & London / UK & Ukraine & US $\$ 155,479$ & US\$36,737 & Successful Efforts \\
\hline $\begin{array}{l}\text { Rockhopper } \\
\text { Exploration }\end{array}$ & AIM & London / UK & Falkland Islands & $£ 149,277$ & $£ 78,273$ & Successful Efforts \\
\hline Rose Petroleum & AIM & London / UK & Mexico; USA & $£ 6,165$ & $£ 5,710$ & Full Cost \\
\hline Roxi Petroleum & AIM & London / UK & $\begin{array}{c}\text { Kazakhstan; Central } \\
\text { Asia }\end{array}$ & US\$173,936 & US\$3,908 & Full Cost \\
\hline Sacoil & AIM & South Africa & Africa & $\begin{array}{c}\text { South African } \\
\text { Rands } \\
1,305,348\end{array}$ & $\begin{array}{l}\text { South African } \\
\text { Rands 177,906 }\end{array}$ & Successful Efforts \\
\hline San Leon Energy & AIM & London / UK & $\begin{array}{l}\text { Europe and North } \\
\text { Africa }\end{array}$ & $€ 307,982$ & $€ 3$ & Not Clearly Stated \\
\hline Sefton Resources & AIM & $\begin{array}{l}\text { Denver / } \\
\text { Colorado }\end{array}$ & California / USA & $\$ 16,122$ & $\$ 4,727$ & Successful Efforts \\
\hline Serica Energy & AIM & London /UK & Europe and Africa & $\$ 106,493$ & $\$(5,008)$ & Not Clearly Stated \\
\hline Sirius Petroleum & AIM & London / UK & Nigeria / Africa & $\$ 1,701$ & $\$(3,867)$ & Successful Efforts \\
\hline Solo Oil & AIM & London / UK & $\begin{array}{c}\text { Europe; Americas; } \\
\text { Africa }\end{array}$ & $£ 12,512$ & $£(3,117)$ & Not Clearly Stated \\
\hline Sound Oil & AIM & Sevenoaks / UK & Italy & $£ 23,681$ & $£ 482$ & Successful Efforts \\
\hline Spitfire Oil & AIM & Perth / Australia & Australia & $\mathrm{A} \$ 9,452$ & $\mathrm{~A} \$(4,538)$ & Area of Interests \\
\hline Sterling Energy & AIM & London / UK & Africa & $\$ 151,061$ & $\$ 18,370$ & Full Cost \\
\hline Tangiers Petroleum & AIM & Perth / Australia & Africa and Alaska & $\$ 17,569$ & $\$ 505$ & Not Clearly Stated \\
\hline Tomco Energy & AIM & Isle of Man & Colorado / USA & $£ 12,982$ & $£ 11$ & Full Cost \\
\hline Tower Resources & AIM & London / UK & Africa & $\$ 32,668$ & $\$(3,336)$ & Successful Efforts \\
\hline Trap Oil & AIM & London / UK & UKCS / UK & $£ 55,441$ & $£ 30,309$ & Not Clearly Stated \\
\hline $\begin{array}{l}\text { Trinity Exploration } \\
\text { \& Production }\end{array}$ & AIM & $\begin{array}{l}\text { San Fernando/ } \\
\text { Trinidad }\end{array}$ & Trinidad & $\$ 375,792$ & $\$ 123,819$ & Successful Efforts \\
\hline Union Jack Oil & AIM & Bath / UK & UKCS / UK & $£ 972$ & $\mathfrak{f ( 7 0 8 )}$ & Successful Efforts \\
\hline Urals Energy & AIM & Cyprus & Russia & $\$ 147,364$ & $\$ 49,884$ & Successful Efforts \\
\hline Victoria Oil and Gas & AIM & London / UK & Cameroon / Africa & $\$ 220,548$ & $\$ 14,729$ & Not Clearly Stated \\
\hline Volga Gas & AIM & London / UK & Russia & $\$ 118,912$ & $\$ 34,621$ & Successful Efforts \\
\hline $\begin{array}{l}\text { Wentworth } \\
\text { Resources }\end{array}$ & AIM & Canada & $\begin{array}{c}\text { Tanzania and } \\
\text { northern } \\
\text { Mozambique / Africa }\end{array}$ & $\$ 139,649$ & $\$ 955$ & Not Clearly Stated \\
\hline Wessex Exploration & AIM & Bath / UK & $\begin{array}{c}\text { America; Europe; } \\
\text { Africa }\end{array}$ & $£ 5,420$ & $£ 6,872$ & Successful Efforts \\
\hline Westmount Energy & AIM & Jersey / France & $\begin{array}{l}\text { No Clear } \\
\text { Information }\end{array}$ & $£ 676$ & $£(205)$ & Not Clearly Stated \\
\hline
\end{tabular}




\begin{tabular}{|c|c|c|c|c|c|c|}
\hline Zoltav Resources & AIM & Jersey / France & Russia and Alaska & $\$ 46,504$ & $\$ 30$ & Successful Efforts \\
\hline \multicolumn{7}{|c|}{ Panel B: FTSE 350 Companies } \\
\hline Afren plc & $\begin{array}{c}\text { FTSE } \\
350\end{array}$ & London / UK & $\begin{array}{l}\text { West Africa; East } \\
\text { Africa; Iraq }\end{array}$ & US\$3,584,400 & US $\$ 1,498,800$ & Successful Efforts \\
\hline BG Group & $\begin{array}{c}\text { FTSE } \\
350\end{array}$ & London / UK & $\begin{array}{c}\text { UK; Norway; } \\
\text { Kazakhstan; Asia; } \\
\text { Middle East; Africa; } \\
\text { Australia; Far East; } \\
\text { USA }\end{array}$ & US\$65,247,000 & US\$18,933,000 & Successful Efforts \\
\hline BP plc & $\begin{array}{c}\text { FTSE } \\
350\end{array}$ & London / UK & $>80$ & $\begin{array}{c}\text { US\$300,193,00 } \\
0\end{array}$ & $\begin{array}{c}\text { US } \$ 375,580,00 \\
0\end{array}$ & Successful Efforts \\
\hline Cairn Energy plc & $\begin{array}{c}\text { FTSE } \\
350\end{array}$ & Edinburgh / UK & $\begin{array}{l}\text { Mediterranean; UK; } \\
\text { Norway }\end{array}$ & US $\$ 4,327,700$ & N/A & $\begin{array}{c}\text { Full Cost pre } 2005 \\
\text { Successful Efforts post } \\
2005\end{array}$ \\
\hline Enquest & $\begin{array}{l}\text { FTSE } \\
350\end{array}$ & Aberdeen / UK & UK; Norway & US\$ $1,484,709$ & US\$ 961,199 & Successful Efforts \\
\hline Essar Energy plc & $\begin{array}{c}\text { FTSE } \\
350\end{array}$ & London / UK & $\begin{array}{l}\text { India; Indonesia; } \\
\text { Madagascar; } \\
\text { Nigeria; Vietnam }\end{array}$ & US\$17,407,600 & US $\$ 20,903,000$ & Area of Interest \\
\hline Exillion Energy plc & $\begin{array}{c}\text { FTSE } \\
350\end{array}$ & Isle of Man & Russia; Siberia & US\$776,463 & US\$301,928 & Successful Efforts \\
\hline Heritage Oil & $\begin{array}{c}\text { FTSE } \\
350\end{array}$ & Jersey / France & $\begin{array}{l}\text { Africa; Russia; } \\
\text { Middle East }\end{array}$ & US $\$ 3,643,159$ & US $\$ 8,834$ & Full Cost \\
\hline JKX Oil \& Gas plc & $\begin{array}{c}\text { FTSE } \\
350\end{array}$ & London / UK & Ukraine; Russia & US\$586,882 & US\$202,858 & Successful Efforts \\
\hline Ophir Energy & $\begin{array}{c}\text { FTSE } \\
350\end{array}$ & London / UK & Australia; Africa & US $\$ 1,281,972$ & US \$ 1,021 & Successful Efforts \\
\hline Premier Oil plc & $\begin{array}{l}\text { FTSE } \\
350\end{array}$ & London / UK & $\begin{array}{c}\text { UK; Norway; Asia; } \\
\text { Middle East; Africa; } \\
\text { Pakistan }\end{array}$ & US $\$ 4,843,600$ & US $\$ 1,406,700$ & $\begin{array}{c}\text { Full Cost pre } 2005 \\
\text { Successful Efforts post } \\
2005\end{array}$ \\
\hline Royal Dutch Shell & $\begin{array}{l}\text { FTSE } \\
350\end{array}$ & London & $\begin{array}{c}\text { Europe; Asia; } \\
\text { America; Africa }\end{array}$ & $\begin{array}{c}\text { US \$ } \\
357,512,000\end{array}$ & $\begin{array}{c}\text { US } \\
\$ 451,235,000\end{array}$ & Successful Efforts \\
\hline $\begin{array}{l}\text { Salamander Energy } \\
\mathrm{Plc}\end{array}$ & $\begin{array}{c}\text { FTSE } \\
350\end{array}$ & London / UK & Indonesia; Thailand & US\$ $1,273,637$ & US $\$ 367,987$ & Successful Efforts \\
\hline Soco International & $\begin{array}{c}\text { FTSE } \\
350\end{array}$ & London & $\begin{array}{l}\text { UK; Africa; Asia; } \\
\text { Russia }\end{array}$ & US $\$ 1,362,500$ & US $\$ 608,100$ & Full Cost \\
\hline Tullow Oil & $\begin{array}{c}\text { FTSE } \\
350\end{array}$ & London & $\begin{array}{c}\text { Europe; Africa; Asia; } \\
\text { America }\end{array}$ & $\begin{array}{c}\text { US \$ } \\
11,508,600\end{array}$ & US $\$ 2,646,900$ & Successful Efforts \\
\hline \multicolumn{7}{|c|}{ Panel C: Hang Seng Companies } \\
\hline CNOOC & $\begin{array}{l}\text { Hang } \\
\text { Seng }\end{array}$ & Hong Kong & $\begin{array}{lr}\text { China, } & \text { Asia, } \\
\text { America, } & \text { Europe; } \\
\text { Africa; } & \end{array}$ & RMB $621,473 \mathrm{~m}$ & RMB $285,857 \mathrm{~m}$ & Successful Efforts \\
\hline PetroChina & $\begin{array}{l}\text { Hang.Sen } \\
\mathrm{g}\end{array}$ & Beijing & China & $\begin{array}{r}\text { RMB } \\
2,168,837 \mathrm{~m}\end{array}$ & $\begin{array}{r}\text { RMB } \\
2,195,296 \mathrm{~m}\end{array}$ & Successful Efforts \\
\hline
\end{tabular}




\begin{tabular}{|c|c|c|c|c|c|c|}
\hline Sinopec Crop & $\begin{array}{l}\text { Hang } \\
\text { Seng }\end{array}$ & Hong Kong & $\begin{array}{lr}\text { China, } & \text { America, } \\
\text { Europe, } & \text { Africa, } \\
\text { Middle } & \text { East, Far } \\
\text { East } & \end{array}$ & $\begin{array}{r}\text { RMB } \\
1,745,307 \mathrm{~m}\end{array}$ & $\begin{array}{r}\mathrm{RMB} \\
2,551,950 \mathrm{~m}\end{array}$ & Successful Efforts \\
\hline \multicolumn{7}{|c|}{ Panel D: NYSE Companies } \\
\hline $\begin{array}{l}\text { Advantage } \quad \text { Oil } \quad \& \\
\text { Gas Ltd }\end{array}$ & NYSE & US & US & US $\$ 1,765.2$ & US\$255,911 & Successful Efforts \\
\hline $\begin{array}{l}\text { American Eagle } \\
\text { Energy Corporation }\end{array}$ & NYSE & US & US & US\$216,197.1 & US $\$ 43,138.9$ & Full Cost \\
\hline Anadarko & NYSE & US & $\begin{array}{l}\text { US; Africa, New } \\
\text { Zealand; China }\end{array}$ & US $\$ 52,589,000$ & US $\$ 2,444,000$ & Successful Efforts \\
\hline Apache Corporation & NYSE & US & $\begin{array}{l}\text { Argentina; Australia; } \\
\text { Canada; Egypt; UK; } \\
\text { US }\end{array}$ & US $\$ 60,737,000$ & US\$17,078,000 & Full Cost \\
\hline \multicolumn{7}{|c|}{ Panel E: Toronto (TSX) Companies } \\
\hline Husky Energy & $\begin{array}{l}\text { Toronto } \\
\text { Stock } \\
\text { Exchange }\end{array}$ & Canada & Canada & $\mathrm{CA} \$ 35,140,000$ & $\mathrm{C} \$ 22,741,000$ & Full Cost \\
\hline Lundin Petroleum & $\begin{array}{l}\text { Toronto } \\
\text { Stock } \\
\text { Exchange }\end{array}$ & Sweden & $\begin{array}{l}\text { Norway; South East } \\
\text { Asia }\end{array}$ & US\$3,294 & US $\$ 1,319$ & Full Cost \\
\hline \multicolumn{7}{|c|}{ Panel F: Fortune Companies } \\
\hline Devon Energy & $\begin{array}{l}\text { Fortune } \\
500\end{array}$ & US & US; Canada & US $\$ 43,326,000$ & US $\$ 7,153,000$ & Full Cost \\
\hline \multicolumn{7}{|c|}{ Panel G: ISEQ Companies } \\
\hline Aminex plc & ISEQ & Ireland & $\begin{array}{l}\text { Tanzania; } \quad \text { Egypt; } \\
\text { USA }\end{array}$ & US\$107,386 & US\$4,914 & Successful Efforts \\
\hline $\begin{array}{l}\text { Petroceltic plc } \\
\text { (formerly Melrose) }\end{array}$ & $\begin{array}{l}\text { AIM, } \\
\text { ISEQ }\end{array}$ & Dublin / Ireland & $\begin{array}{l}\text { Egypt; Bulgaria; US; } \\
\text { France; Turkey }\end{array}$ & US\$946,029 & US\$59,435 & $\begin{array}{r}\text { Full Cost pre } 2005 \\
\text { Successful Efforts post } \\
2005\end{array}$ \\
\hline
\end{tabular}

\section{Table B: Compliance Checklist of Sample Companies}

\begin{tabular}{|c|c|c|c|c|c|c|c|}
\hline Company & Listing & $\begin{array}{l}\text { Accounting } \\
\text { Method }\end{array}$ & $\begin{array}{l}\text { Measurement } \\
\text { of E\&E Assets }\end{array}$ & $\begin{array}{c}\text { Classification } \\
\text { of Oil and Gas } \\
\text { Assets }\end{array}$ & $\begin{array}{c}\text { Impairment } \\
\text { Assessment } \\
\text { for E\&E } \\
\text { Assets }\end{array}$ & $\begin{array}{c}\text { Disclosure } \\
\text { of E\&E } \\
\text { Assets }\end{array}$ & Reference \\
\hline \multicolumn{8}{|c|}{ Panel A: AIM Companies } \\
\hline $\begin{array}{c}\text { 3 Legs } \\
\text { Resources plc }\end{array}$ & AIM & Full Cost & Cost & $\begin{array}{l}\text { Intangibles and } \\
\text { non-intangibles }\end{array}$ & YES & YES & $\begin{array}{c}\text { Annual } \\
\text { Report } 2012\end{array}$ \\
\hline $\begin{array}{c}\text { Amerisur } \\
\text { Resources plc }\end{array}$ & AIM & $\begin{array}{l}\text { Successful } \\
\text { Efforts }\end{array}$ & Cost & $\begin{array}{l}\text { Intangibles and } \\
\text { non-intangibles }\end{array}$ & YES & YES & $\begin{array}{c}\text { Annual } \\
\text { Report 2012 }\end{array}$ \\
\hline
\end{tabular}




\begin{tabular}{|c|c|c|c|c|c|c|c|}
\hline $\begin{array}{c}\text { Andes Energia } \\
\text { Plc }\end{array}$ & AIM & $\begin{array}{l}\text { Successful } \\
\text { Efforts }\end{array}$ & Valuation & $\begin{array}{l}\text { Intangibles and } \\
\text { non-intangibles }\end{array}$ & YES & YES & $\begin{array}{c}\text { Annual } \\
\text { Report } 2013\end{array}$ \\
\hline Antrim Energy & AIM & $\begin{array}{l}\text { Successful } \\
\text { Efforts }\end{array}$ & Cost & $\begin{array}{l}\text { Intangible } \\
\text { Assets }\end{array}$ & YES & YES & $\begin{array}{c}\text { Annual } \\
\text { Report } 2013\end{array}$ \\
\hline $\begin{array}{c}\text { Argos } \\
\text { Resources }\end{array}$ & AIM & Full Cost & Cost & $\begin{array}{c}\text { Intangible } \\
\text { Assets }\end{array}$ & YES & YES & $\begin{array}{c}\text { Annual } \\
\text { Report } 2013\end{array}$ \\
\hline $\begin{array}{c}\text { Ascent } \\
\text { Resources plc }\end{array}$ & AIM & $\begin{array}{l}\text { Successful } \\
\text { Efforts }\end{array}$ & Cost & $\begin{array}{l}\text { Intangibles and } \\
\text { non-intangibles }\end{array}$ & YES & YES & $\begin{array}{c}\text { Annual } \\
\text { Report } 2011\end{array}$ \\
\hline $\begin{array}{c}\text { Azonto } \\
\text { Petroleum }\end{array}$ & AIM & $\begin{array}{l}\text { Area of } \\
\text { Interest }\end{array}$ & Cost & $\begin{array}{l}\text { Exploration } \\
\text { Assets }\end{array}$ & YES & YES & $\begin{array}{c}\text { Annual } \\
\text { Report } 2013\end{array}$ \\
\hline $\begin{array}{c}\text { Bahamas } \\
\text { Petroleum } \\
\text { Company plc }\end{array}$ & AIM & $\begin{array}{l}\text { Area of } \\
\text { Interest }\end{array}$ & Cost & $\begin{array}{l}\text { Intangibles and } \\
\text { non-intangibles }\end{array}$ & YES & YES & $\begin{array}{c}\text { Annual } \\
\text { Reports } \\
2011 \& \\
2012\end{array}$ \\
\hline Baron Oil Plc & AIM & $\begin{array}{l}\text { Successful } \\
\text { Efforts }\end{array}$ & Cost & $\begin{array}{l}\text { Intangibles and } \\
\text { non-intangibles }\end{array}$ & YES & YES & $\begin{array}{c}\text { Annual } \\
\text { Reports } \\
2013\end{array}$ \\
\hline $\begin{array}{c}\text { Bankers } \\
\text { Petroleum }\end{array}$ & AIM & Full Cost & Cost & $\begin{array}{l}\text { Intangibles and } \\
\text { non-intangibles }\end{array}$ & YES & YES & $\begin{array}{c}\text { Annual } \\
\text { Reports } \\
2013\end{array}$ \\
\hline $\begin{array}{c}\text { Borders \& } \\
\text { Southern } \\
\text { Petroleum plc }\end{array}$ & AIM & Full Cost & Cost & $\begin{array}{l}\text { Intangibles and } \\
\text { non-intangibles }\end{array}$ & YES & YES & $\begin{array}{c}\text { Annual } \\
\text { Report } 2013\end{array}$ \\
\hline BowLeven plc & AIM & $\begin{array}{l}\text { Successful } \\
\text { Efforts }\end{array}$ & Cost & $\begin{array}{l}\text { Intangibles and } \\
\text { non-intangibles }\end{array}$ & Not Clear & Yes & $\begin{array}{c}\text { Annual } \\
\text { Report } 2013\end{array}$ \\
\hline $\begin{array}{c}\text { Cadogan } \\
\text { Petroleum plc }\end{array}$ & AIM & Full Cost & Cost & $\begin{array}{l}\text { Intangibles and } \\
\text { non-intangibles }\end{array}$ & YES & YES & $\begin{array}{c}\text { Annual } \\
\text { Report } 2013\end{array}$ \\
\hline $\begin{array}{c}\text { Caza Oil and } \\
\text { Gas }\end{array}$ & AIM & $\begin{array}{l}\text { Not Clearly } \\
\text { Stated }\end{array}$ & Cost & $\begin{array}{l}\text { Intangibles and } \\
\text { non-intangibles }\end{array}$ & YES & YES & $\begin{array}{c}\text { Annual } \\
\text { Report } 2013\end{array}$ \\
\hline $\begin{array}{c}\text { Chariot Oil and } \\
\text { Gas }\end{array}$ & AIM & Full Cost & Cost & NO & NO & $\mathrm{NO}$ & $\begin{array}{c}\text { Annual } \\
\text { Report } 2013\end{array}$ \\
\hline Circle Oil plc & AIM & Full Cost & Cost & $\begin{array}{l}\text { Intangibles and } \\
\text { non-intangibles }\end{array}$ & YES & YES & $\begin{array}{c}\text { Annual } \\
\text { Report } 2013\end{array}$ \\
\hline $\begin{array}{c}\text { Clontarf Energy } \\
\text { plc }\end{array}$ & AIM & $\begin{array}{l}\text { Successful } \\
\text { Efforts }\end{array}$ & Cost & $\begin{array}{l}\text { Intangibles and } \\
\text { non-intangibles }\end{array}$ & YES & YES & $\begin{array}{c}\text { Annual } \\
\text { Report } 2013\end{array}$ \\
\hline $\begin{array}{c}\text { Dana Petroleum } \\
\text { plc }\end{array}$ & AIM & Full Cost & Cost & $\begin{array}{l}\text { Intangibles and } \\
\text { non-intangibles }\end{array}$ & YES & YES & $\begin{array}{c}\text { Annual } \\
\text { Report } 2013\end{array}$ \\
\hline $\begin{array}{c}\text { Desire } \\
\text { Petroleum plc } \\
\text { Acquired by } \\
\text { Falkland Oil } \\
\text { and Gas Ltd in } \\
\text { Dec } 2013\end{array}$ & AIM & $\begin{array}{l}\text { (Successful } \\
\text { Efforts) } \\
\text { The group } \\
\text { applies Full } \\
\text { Cost }\end{array}$ & Cost & $\begin{array}{l}\text { Intangibles and } \\
\text { non-intangibles }\end{array}$ & YES & YES & $\begin{array}{c}\text { Annual } \\
\text { Reports } \\
2011 \text { and } \\
2013\end{array}$ \\
\hline $\begin{array}{c}\text { Egdon } \\
\text { Resources plc }\end{array}$ & AIM & Full Cost & Cost & $\begin{array}{l}\text { Intangibles and } \\
\text { non-intangibles }\end{array}$ & YES & YES & $\begin{array}{c}\text { Annual } \\
\text { Report } 2013\end{array}$ \\
\hline Enegi Oil & AIM & No Clearly & Cost & Intangibles and & YES & YES & Annual \\
\hline
\end{tabular}




\begin{tabular}{|c|c|c|c|c|c|c|c|}
\hline & & Stated & & non-intangibles & & & Report 2013 \\
\hline Energy XXI & AIM & Full Cost & Cost & $\begin{array}{l}\text { Intangibles and } \\
\text { non-intangibles }\end{array}$ & YES & YES & $\begin{array}{c}\text { Annual } \\
\text { Report } 2014\end{array}$ \\
\hline $\begin{array}{c}\text { Eland Oil and } \\
\text { Gas }\end{array}$ & AIM & $\begin{array}{c}\text { Not Clearly } \\
\text { Stated }\end{array}$ & Cost & $\mathrm{NO}$ & NO & NO & $\begin{array}{c}\text { Annual } \\
\text { Report } 2013\end{array}$ \\
\hline $\begin{array}{l}\text { Empyrean } \\
\text { Energy plc }\end{array}$ & AIM & $\begin{array}{c}\text { Area of } \\
\text { Interest pre } \\
\text { 2014- Full } \\
\text { Cost from } \\
2014\end{array}$ & Cost & $\begin{array}{l}\text { Intangibles and } \\
\text { non-intangibles }\end{array}$ & YES & YES & $\begin{array}{c}\text { Annual } \\
\text { Reports } \\
2013 \text { and } \\
2014\end{array}$ \\
\hline $\begin{array}{c}\text { Europa Oil \& } \\
\text { Gas plc }\end{array}$ & AIM & Full Cost & Cost & $\begin{array}{l}\text { Intangibles and } \\
\text { non-intangibles }\end{array}$ & YES & YES & $\begin{array}{c}\text { Annual } \\
\text { Report } 2013\end{array}$ \\
\hline $\begin{array}{c}\text { Falcon Oil and } \\
\text { Gas }\end{array}$ & AIM & Full Cost & Cost & $\begin{array}{l}\text { Intangibles and } \\
\text { non-intangibles }\end{array}$ & YES & YES & $\begin{array}{c}\text { Annual } \\
\text { Report } 2013\end{array}$ \\
\hline $\begin{array}{l}\text { Falkland Oil } \\
\text { and Gas }\end{array}$ & AIM & Full Cost & Cost & $\begin{array}{l}\text { Intangibles and } \\
\text { non-intangibles }\end{array}$ & YES & YES & $\begin{array}{c}\text { Annual } \\
\text { Report } 2013\end{array}$ \\
\hline $\begin{array}{c}\text { Faroe } \\
\text { Petroleum plc }\end{array}$ & AIM & Full Cost & Cost & $\begin{array}{l}\text { Intangibles and } \\
\text { non-intangibles }\end{array}$ & YES & YES & $\begin{array}{c}\text { Annual } \\
\text { Report } 2013\end{array}$ \\
\hline $\begin{array}{c}\text { Fastnet Oil and } \\
\text { Gas }\end{array}$ & AIM & $\begin{array}{l}\text { Not Clearly } \\
\text { Stated }\end{array}$ & Cost & NO & YES & NO & $\begin{array}{c}\text { Annual } \\
\text { Report } 2014\end{array}$ \\
\hline $\begin{array}{c}\text { Forum Energy } \\
\text { plc }\end{array}$ & AIM & Full Cost & Cost & $\begin{array}{l}\text { Intangibles and } \\
\text { non-intangibles }\end{array}$ & YES & YES & $\begin{array}{c}\text { Annual } \\
\text { Report } 2013\end{array}$ \\
\hline $\begin{array}{l}\text { Frontera } \\
\text { Resources }\end{array}$ & AIM & Full Cost & Cost & $\mathrm{NO}$ & NO & NO & $\begin{array}{c}\text { Annual } \\
\text { Report } 2013\end{array}$ \\
\hline $\begin{array}{c}\text { Global } \\
\text { Petroleum Ltd }\end{array}$ & $\begin{array}{l}\text { AIM (and } \\
\text { ASX) }\end{array}$ & $\begin{array}{l}\text { Area of } \\
\text { Interest }\end{array}$ & Cost & $\mathrm{NO}$ & YES & YES & $\begin{array}{c}\text { Annual } \\
\text { Report } 2014\end{array}$ \\
\hline $\begin{array}{l}\text { Gulfsands } \\
\text { Petroleum }\end{array}$ & AIM & $\begin{array}{l}\text { Successful } \\
\text { Efforts }\end{array}$ & Cost & $\begin{array}{l}\text { Intangibles and } \\
\text { non-intangibles }\end{array}$ & YES & YES & $\begin{array}{c}\text { Annual } \\
\text { Report } 2013\end{array}$ \\
\hline $\begin{array}{l}\text { Hurrican } \\
\text { Energy }\end{array}$ & AIM & $\begin{array}{l}\text { Successful } \\
\text { Efforts }\end{array}$ & Cost & $\begin{array}{l}\text { Intangibles and } \\
\text { non-intangibles }\end{array}$ & YES & YES & $\begin{array}{c}\text { Annual } \\
\text { Report } 2013\end{array}$ \\
\hline IGas Energy & AIM & $\begin{array}{l}\text { Successful } \\
\text { Efforts }\end{array}$ & Cost & $\begin{array}{l}\text { Intangibles and } \\
\text { non-intangibles }\end{array}$ & YES & YES & $\begin{array}{c}\text { Annual } \\
\text { Report } 2013\end{array}$ \\
\hline $\begin{array}{l}\text { Independent } \\
\text { Resources }\end{array}$ & AIM & $\begin{array}{l}\text { Not Clearly } \\
\text { Stated }\end{array}$ & Cost & $\begin{array}{l}\text { Intangibles and } \\
\text { non-intangibles }\end{array}$ & YES & YES & $\begin{array}{c}\text { Annual } \\
\text { Report } 2013\end{array}$ \\
\hline $\begin{array}{l}\text { Independent Oil } \\
\text { and GAs }\end{array}$ & AIM & $\begin{array}{l}\text { Successful } \\
\text { Efforts }\end{array}$ & Cost & $\begin{array}{l}\text { Intangibles and } \\
\text { non-intangibles }\end{array}$ & YES & YES & $\begin{array}{c}\text { Annual } \\
\text { Report } 2013\end{array}$ \\
\hline Indus Gas Ltd & AIM & Full Cost & Cost & $\begin{array}{l}\text { Intangibles and } \\
\text { non-intangibles }\end{array}$ & YES & YES & $\begin{array}{c}\text { Annual } \\
\text { Report } 2013\end{array}$ \\
\hline InfraStrata Plc & AIM & Full Cost & Cost & $\begin{array}{l}\text { Intangibles and } \\
\text { non-intangibles }\end{array}$ & YES & YES & $\begin{array}{c}\text { Annual } \\
\text { Report } 2014\end{array}$ \\
\hline $\begin{array}{c}\text { Ithaca Energy } \\
\text { Ltd }\end{array}$ & AIM & $\begin{array}{l}\text { Not Clearly } \\
\text { Stated }\end{array}$ & Cost & $\begin{array}{l}\text { Intangibles and } \\
\text { non-intangibles }\end{array}$ & YES & YES & $\begin{array}{c}\text { Annual } \\
\text { Report } 2014\end{array}$ \\
\hline Jubilant Energy & AIM & $\begin{array}{l}\text { Not Clearly } \\
\text { Stated }\end{array}$ & Cost & $\begin{array}{l}\text { Intangibles and } \\
\text { non-intangibles }\end{array}$ & YES & YES & $\begin{array}{c}\text { Annual } \\
\text { Report } 2013\end{array}$ \\
\hline
\end{tabular}




\begin{tabular}{|c|c|c|c|c|c|c|c|}
\hline $\begin{array}{c}\text { Jupiter Energy } \\
\text { Ltd }\end{array}$ & AIM & $\begin{array}{l}\text { Area of } \\
\text { Interest }\end{array}$ & Cost & $\begin{array}{l}\text { Intangibles and } \\
\text { non-intangibles }\end{array}$ & YES & YES & $\begin{array}{c}\text { Annual } \\
\text { Report } 2014\end{array}$ \\
\hline $\begin{array}{c}\text { Kea Petroleum } \\
\text { Plc }\end{array}$ & AIM & Full Cost & Cost & $\begin{array}{l}\text { Intangibles and } \\
\text { non-intangibles }\end{array}$ & YES & YES & $\begin{array}{c}\text { Annual } \\
\text { Report } 2013\end{array}$ \\
\hline $\begin{array}{l}\text { Lansdowne Oil } \\
\text { and Gas }\end{array}$ & AIM & $\begin{array}{l}\text { Successful } \\
\text { Efforts }\end{array}$ & Cost & $\begin{array}{l}\text { Intangibles and } \\
\text { non-intangibles }\end{array}$ & YES & YES & $\begin{array}{c}\text { Annual } \\
\text { Report } 2013\end{array}$ \\
\hline LekOil & AIM & Full Cost & Cost & $\begin{array}{l}\text { Intangibles and } \\
\text { non-intangibles }\end{array}$ & YES & YES & $\begin{array}{c}\text { Annual } \\
\text { Report } 2013\end{array}$ \\
\hline Leyshon Energy & AIM & $\begin{array}{l}\text { Successful } \\
\text { Efforts }\end{array}$ & Cost & $\begin{array}{l}\text { Intangibles and } \\
\text { non-intangibles }\end{array}$ & YES & YES & $\begin{array}{c}\text { Annual } \\
\text { Report } 2013\end{array}$ \\
\hline $\begin{array}{l}\text { LGO Energy } \\
\text { Plc }\end{array}$ & AIM & $\begin{array}{l}\text { Successful } \\
\text { Efforts }\end{array}$ & Cost & $\begin{array}{l}\text { Intangibles and } \\
\text { non-intangibles }\end{array}$ & YES & YES & $\begin{array}{c}\text { Annual } \\
\text { Report } 2013\end{array}$ \\
\hline Madagascar Oil & AIM & Full Cost & Cost & $\begin{array}{l}\text { Intangibles and } \\
\text { non-intangibles }\end{array}$ & YES & YES & $\begin{array}{c}\text { Annual } \\
\text { Report } 2013\end{array}$ \\
\hline $\begin{array}{l}\text { Magnolia } \\
\text { Petroleum }\end{array}$ & AIM & $\begin{array}{l}\text { Successful } \\
\text { Efforts }\end{array}$ & Cost & $\begin{array}{l}\text { Intangibles and } \\
\text { non-intangibles }\end{array}$ & YES & YES & $\begin{array}{c}\text { Annual } \\
\text { Report } 2013\end{array}$ \\
\hline Maple Energy & AIM & $\begin{array}{l}\text { Successful } \\
\text { Efforts }\end{array}$ & Cost & $\begin{array}{l}\text { Intangibles and } \\
\text { non-intangibles }\end{array}$ & YES & YES & $\begin{array}{c}\text { Annual } \\
\text { Report } 2013\end{array}$ \\
\hline Max Petroleum & AIM & $\begin{array}{l}\text { Successful } \\
\text { Efforts }\end{array}$ & Cost & $\begin{array}{l}\text { Intangibles and } \\
\text { non-intangibles }\end{array}$ & YES & YES & $\begin{array}{c}\text { Annual } \\
\text { Report } 2014\end{array}$ \\
\hline $\begin{array}{l}\text { Mercom Oil } \\
\text { Sands }\end{array}$ & AIM & $\begin{array}{l}\text { Not Clearly } \\
\text { Stated }\end{array}$ & Cost & $\begin{array}{l}\text { Intangibles and } \\
\text { non-intangibles }\end{array}$ & YES & YES & $\begin{array}{c}\text { Annual } \\
\text { Report } 2013\end{array}$ \\
\hline $\begin{array}{c}\text { Masoman Oil } \\
\text { and Gas }\end{array}$ & AIM & $\begin{array}{l}\text { Area of } \\
\text { Interest }\end{array}$ & Cost & $\begin{array}{l}\text { Intangibles and } \\
\text { non-intangibles }\end{array}$ & YES & YES & $\begin{array}{c}\text { Annual } \\
\text { Report } 2013\end{array}$ \\
\hline New World Oil & AIM & $\begin{array}{l}\text { Not Clearly } \\
\text { Stated }\end{array}$ & Cost & $\begin{array}{l}\text { Intangibles and } \\
\text { non-intangibles }\end{array}$ & YES & YES & $\begin{array}{c}\text { Annual } \\
\text { Report } 2013\end{array}$ \\
\hline $\begin{array}{l}\text { Nighthawk } \\
\text { Energy Plc }\end{array}$ & AIM & $\begin{array}{l}\text { Successful } \\
\text { Efforts }\end{array}$ & Cost & $\begin{array}{l}\text { Intangibles and } \\
\text { non-intangibles }\end{array}$ & YES & YES & $\begin{array}{c}\text { Annual } \\
\text { Report } 2013\end{array}$ \\
\hline $\begin{array}{l}\text { Northcot } \\
\text { Energy }\end{array}$ & AIM & Full Cost & Cost & $\begin{array}{l}\text { Intangibles and } \\
\text { non-intangibles }\end{array}$ & YES & YES & $\begin{array}{c}\text { Annual } \\
\text { Report } 2013\end{array}$ \\
\hline $\begin{array}{l}\text { Northern } \\
\text { Petroleum }\end{array}$ & AIM & Full Cost & Cost & $\begin{array}{l}\text { Intangibles and } \\
\text { non-intangibles }\end{array}$ & YES & YES & $\begin{array}{c}\text { Annual } \\
\text { Report } 2013\end{array}$ \\
\hline $\begin{array}{l}\text { Nostra Terra } \\
\text { Oil and Gas }\end{array}$ & AIM & $\begin{array}{l}\text { Successful } \\
\text { Efforts }\end{array}$ & Cost & $\begin{array}{l}\text { Intangibles and } \\
\text { non-intangibles }\end{array}$ & YES & YES & $\begin{array}{c}\text { Annual } \\
\text { Report } 2013\end{array}$ \\
\hline Oilex Petroleum & AIM & $\begin{array}{l}\text { Successful } \\
\text { Efforts }\end{array}$ & Cost & $\begin{array}{l}\text { Intangibles and } \\
\text { non-intangibles }\end{array}$ & YES & YES & $\begin{array}{c}\text { Annual } \\
\text { Report } 2014\end{array}$ \\
\hline $\begin{array}{c}\text { Pantheon } \\
\text { Resources Plc }\end{array}$ & AIM & $\begin{array}{l}\text { Successful } \\
\text { Efforts }\end{array}$ & Cost & $\begin{array}{l}\text { Intangibles and } \\
\text { non-intangibles }\end{array}$ & YES & YES & $\begin{array}{c}\text { Annual } \\
\text { Report } 2014\end{array}$ \\
\hline $\begin{array}{l}\text { Parkmead } \\
\text { Group Plc }\end{array}$ & AIM & $\begin{array}{l}\text { Not Clearly } \\
\text { Stated }\end{array}$ & Cost & $\begin{array}{l}\text { Intangibles and } \\
\text { non-intangibles }\end{array}$ & YES & YES & $\begin{array}{c}\text { Annual } \\
\text { Report 2014 }\end{array}$ \\
\hline $\begin{array}{c}\text { Petrel } \\
\text { Resources }\end{array}$ & AIM & $\begin{array}{l}\text { Not Clearly } \\
\text { Stated }\end{array}$ & Cost & $\begin{array}{l}\text { Intangibles and } \\
\text { non-intangibles }\end{array}$ & YES & YES & $\begin{array}{c}\text { Annual } \\
\text { Report } 2013\end{array}$ \\
\hline Petro Matad Ltd & AIM & $\begin{array}{l}\text { Area of } \\
\text { Interest }\end{array}$ & Cost & $\begin{array}{l}\text { Intangibles and } \\
\text { non-intangibles }\end{array}$ & YES & YES & $\begin{array}{c}\text { Annual } \\
\text { Report } 2013\end{array}$ \\
\hline
\end{tabular}




\begin{tabular}{|c|c|c|c|c|c|c|c|}
\hline $\begin{array}{c}\text { Petroceltic plc } \\
\text { (formerly } \\
\text { Melrose) }\end{array}$ & $\begin{array}{l}\text { AIM, } \\
\text { ISEQ }\end{array}$ & $\begin{array}{l}\text { Full Cost pre } \\
2005 \\
\\
\text { Successful } \\
\text { Efforts post } \\
2005\end{array}$ & Cost & $\begin{array}{l}\text { Intangibles and } \\
\text { non-intangibles }\end{array}$ & YES & YES & $\begin{array}{c}\text { Annual } \\
\text { Report } 2013\end{array}$ \\
\hline $\begin{array}{l}\text { PetroNeft } \\
\text { Resources Ltd }\end{array}$ & $\begin{array}{l}\text { AIM } \\
\text { ESM }\end{array}$ & $\begin{array}{l}\text { Successful } \\
\text { Efforts }\end{array}$ & Cost & $\begin{array}{l}\text { Intangibles and } \\
\text { non-intangibles }\end{array}$ & YES & YES & $\begin{array}{c}\text { Annual } \\
\text { Report } 2013\end{array}$ \\
\hline $\begin{array}{l}\text { President } \\
\text { Energy Plc }\end{array}$ & AIM & $\begin{array}{l}\text { Successful } \\
\text { Efforts }\end{array}$ & Cost & $\begin{array}{l}\text { Intangibles and } \\
\text { non-intangibles }\end{array}$ & YES & YES & $\begin{array}{c}\text { Annual } \\
\text { Report } 2013\end{array}$ \\
\hline $\begin{array}{l}\text { Providence } \\
\text { Resources }\end{array}$ & AIM & Full Cost & Cost & $\begin{array}{l}\text { Intangibles and } \\
\text { non-intangibles }\end{array}$ & YES & YES & $\begin{array}{c}\text { Annual } \\
\text { Report } 2013\end{array}$ \\
\hline $\begin{array}{l}\text { Range } \\
\text { Resources }\end{array}$ & AIM & $\begin{array}{l}\text { Area of } \\
\text { Interest }\end{array}$ & Cost & $\begin{array}{l}\text { Intangibles and } \\
\text { non-intangibles }\end{array}$ & YES & YES & $\begin{array}{c}\text { Annual } \\
\text { Report 2014 }\end{array}$ \\
\hline $\begin{array}{l}\text { Red Emperor } \\
\text { Resources }\end{array}$ & AIM & $\begin{array}{l}\text { Area } \\
\text { Interest }\end{array}$ & Cost & $\begin{array}{l}\text { Intangibles and } \\
\text { non-intangibles }\end{array}$ & YES & YES & $\begin{array}{c}\text { Annual } \\
\text { Report 2014 }\end{array}$ \\
\hline $\begin{array}{l}\text { Regal } \\
\text { Petroleum }\end{array}$ & AIM & $\begin{array}{l}\text { Successful } \\
\text { Efforts }\end{array}$ & Cost & $\begin{array}{l}\text { Intangibles and } \\
\text { non-intangibles }\end{array}$ & YES & YES & $\begin{array}{c}\text { Annual } \\
\text { Report } 2013\end{array}$ \\
\hline $\begin{array}{l}\text { Rockhopper } \\
\text { Exploration }\end{array}$ & AIM & $\begin{array}{l}\text { Successful } \\
\text { Efforts }\end{array}$ & Cost & $\begin{array}{l}\text { Intangibles and } \\
\text { non-intangibles }\end{array}$ & YES & YES & $\begin{array}{c}\text { Annual } \\
\text { Report } 2013\end{array}$ \\
\hline Rose Petroleum & AIM & Full Cost & Cost & $\begin{array}{l}\text { Intangibles and } \\
\text { non-intangibles }\end{array}$ & YES & YES & $\begin{array}{c}\text { Annual } \\
\text { Report } 2013\end{array}$ \\
\hline Roxi Petroleum & AIM & Full Cost & Cost & $\begin{array}{l}\text { Intangibles and } \\
\text { non-intangibles }\end{array}$ & YES & YES & $\begin{array}{c}\text { Annual } \\
\text { Report } 2013\end{array}$ \\
\hline Sacoil & AIM & $\begin{array}{l}\text { Successful } \\
\text { Efforts }\end{array}$ & Cost & $\begin{array}{l}\text { Intangibles and } \\
\text { non-intangibles }\end{array}$ & YES & YES & $\begin{array}{c}\text { Annual } \\
\text { Report } 2014\end{array}$ \\
\hline San Leon & AIM & $\begin{array}{l}\text { Not Clearly } \\
\text { Stated }\end{array}$ & Cost & $\begin{array}{l}\text { Intangibles and } \\
\text { non-intangibles }\end{array}$ & YES & YES & $\begin{array}{c}\text { Annual } \\
\text { Report } 2013\end{array}$ \\
\hline $\begin{array}{c}\text { Sefton } \\
\text { Resources }\end{array}$ & AIM & $\begin{array}{l}\text { Successful } \\
\text { Efforts }\end{array}$ & Cost & $\begin{array}{l}\text { Intangibles and } \\
\text { non-intangibles }\end{array}$ & YES & YES & $\begin{array}{c}\text { Annual } \\
\text { Report } 2013\end{array}$ \\
\hline Serica Energy & AIM & $\begin{array}{l}\text { Not Clearly } \\
\text { Stated }\end{array}$ & Cost & $\begin{array}{l}\text { Intangibles and } \\
\text { non-intangibles }\end{array}$ & YES & YES & $\begin{array}{c}\text { Annual } \\
\text { Report } 2013\end{array}$ \\
\hline $\begin{array}{c}\text { Sirius } \\
\text { Petroleum }\end{array}$ & AIM & $\begin{array}{l}\text { Successful } \\
\text { Efforts }\end{array}$ & Cost & $\begin{array}{l}\text { Intangibles and } \\
\text { non-intangibles }\end{array}$ & YES & YES & $\begin{array}{c}\text { Annual } \\
\text { Report 2012 }\end{array}$ \\
\hline Solo Oil & AIM & $\begin{array}{l}\text { Not Clearly } \\
\text { Stated }\end{array}$ & Cost & $\begin{array}{l}\text { Intangibles and } \\
\text { non-intangibles }\end{array}$ & YES & YES & $\begin{array}{c}\text { Annual } \\
\text { Report } 2013\end{array}$ \\
\hline Sound Oil & AIM & $\begin{array}{l}\text { Successful } \\
\text { Efforts }\end{array}$ & Cost & $\begin{array}{l}\text { Intangibles and } \\
\text { non-intangibles }\end{array}$ & YES & YES & $\begin{array}{c}\text { Annual } \\
\text { Report } 2013\end{array}$ \\
\hline Spitfire Oil & AIM & $\begin{array}{l}\text { Area of } \\
\text { Interests }\end{array}$ & Cost & $\begin{array}{l}\text { Intangibles and } \\
\text { non-intangibles }\end{array}$ & YES & YES & $\begin{array}{c}\text { Annual } \\
\text { Report } 2014\end{array}$ \\
\hline Sterling Energy & AIM & Full Cost & Cost & $\begin{array}{l}\text { Intangibles and } \\
\text { non-intangibles }\end{array}$ & YES & YES & $\begin{array}{c}\text { Annual } \\
\text { Report } 2013\end{array}$ \\
\hline $\begin{array}{l}\text { Tangiers } \\
\text { Petroleum }\end{array}$ & AIM & $\begin{array}{l}\text { Not Clearly } \\
\text { Stated }\end{array}$ & Cost & $\begin{array}{l}\text { Intangibles and } \\
\text { non-intangibles }\end{array}$ & YES & YES & $\begin{array}{c}\text { Annual } \\
\text { Report } 2013\end{array}$ \\
\hline
\end{tabular}




\begin{tabular}{|c|c|c|c|c|c|c|c|}
\hline Tomco Energy & AIM & Full Cost & Cost & $\begin{array}{l}\text { Intangibles and } \\
\text { non-intangibles }\end{array}$ & YES & YES & $\begin{array}{c}\text { Annual } \\
\text { Report } 2013\end{array}$ \\
\hline $\begin{array}{c}\text { Tower } \\
\text { Resources }\end{array}$ & AIM & $\begin{array}{l}\text { Successful } \\
\text { Efforts }\end{array}$ & Cost & $\begin{array}{l}\text { Intangibles and } \\
\text { non-intangibles }\end{array}$ & YES & YES & $\begin{array}{c}\text { Annual } \\
\text { Report } 2013\end{array}$ \\
\hline Trap Oil & AIM & $\begin{array}{c}\text { Not Clearly } \\
\text { Stated }\end{array}$ & Cost & $\begin{array}{l}\text { Intangibles and } \\
\text { non-intangibles }\end{array}$ & YES & YES & $\begin{array}{c}\text { Annual } \\
\text { Report } 2013\end{array}$ \\
\hline $\begin{array}{c}\text { Trinity } \\
\text { Exploration \& } \\
\text { Production }\end{array}$ & AIM & $\begin{array}{l}\text { Successful } \\
\text { Efforts }\end{array}$ & Cost & $\begin{array}{l}\text { Intangibles and } \\
\text { non-intangibles }\end{array}$ & YES & YES & $\begin{array}{c}\text { Annual } \\
\text { Report } 2013\end{array}$ \\
\hline Union Jack Oil & AIM & $\begin{array}{l}\text { Successful } \\
\text { Efforts }\end{array}$ & Cost & $\begin{array}{l}\text { Intangibles and } \\
\text { non-intangibles }\end{array}$ & YES & YES & $\begin{array}{c}\text { Annual } \\
\text { Report } 2013\end{array}$ \\
\hline Urals Energy & AIM & $\begin{array}{l}\text { Successful } \\
\text { Efforts }\end{array}$ & Cost & $\begin{array}{l}\text { Intangibles and } \\
\text { non-intangibles }\end{array}$ & YES & YES & $\begin{array}{c}\text { Annual } \\
\text { Report } 2012\end{array}$ \\
\hline $\begin{array}{c}\text { Victoria Oil and } \\
\text { Gas }\end{array}$ & AIM & $\begin{array}{l}\text { Not Clearly } \\
\text { Stated }\end{array}$ & Cost & $\begin{array}{l}\text { Intangibles and } \\
\text { non-intangibles }\end{array}$ & YES & YES & $\begin{array}{c}\text { Annual } \\
\text { Report } 2014\end{array}$ \\
\hline Volga Gas & AIM & $\begin{array}{l}\text { Successful } \\
\text { Efforts }\end{array}$ & Cost & $\begin{array}{l}\text { Intangibles and } \\
\text { non-intangibles }\end{array}$ & YES & YES & $\begin{array}{c}\text { Annual } \\
\text { Report } 2013\end{array}$ \\
\hline $\begin{array}{l}\text { Wentworth } \\
\text { Resources }\end{array}$ & AIM & $\begin{array}{l}\text { Not Clearly } \\
\text { Stated }\end{array}$ & Cost & $\begin{array}{l}\text { Intangibles and } \\
\text { non-intangibles }\end{array}$ & YES & YES & $\begin{array}{c}\text { Annual } \\
\text { Report } 2013\end{array}$ \\
\hline $\begin{array}{c}\text { Wessex } \\
\text { Exploration }\end{array}$ & AIM & $\begin{array}{l}\text { Successful } \\
\text { Efforts }\end{array}$ & Cost & $\begin{array}{l}\text { Intangibles and } \\
\text { non-intangibles }\end{array}$ & YES & YES & $\begin{array}{c}\text { Annual } \\
\text { Report } 2014\end{array}$ \\
\hline $\begin{array}{l}\text { Westmount } \\
\text { Energy }\end{array}$ & AIM & $\begin{array}{l}\text { Not Clearly } \\
\text { Stated }\end{array}$ & Cost & $\mathrm{NO}$ & NO & NO & $\begin{array}{c}\text { Annual } \\
\text { Report } 2014\end{array}$ \\
\hline $\begin{array}{c}\text { Zoltav } \\
\text { Resources }\end{array}$ & AIM & $\begin{array}{l}\text { Successful } \\
\text { Efforts }\end{array}$ & Cost & $\begin{array}{l}\text { Intangibles and } \\
\text { non-intangibles }\end{array}$ & YES & YES & $\begin{array}{c}\text { Annual } \\
\text { Report } 2013\end{array}$ \\
\hline \multicolumn{8}{|c|}{ Panel B: FTSE 350 Companies } \\
\hline Afren plc & FTSE 350 & $\begin{array}{l}\text { Successful } \\
\text { Efforts }\end{array}$ & Cost & $\begin{array}{l}\text { Intangibles and } \\
\text { non-intangibles }\end{array}$ & YES & YES & $\begin{array}{c}\text { Annual } \\
\text { Report } \\
2011-2013\end{array}$ \\
\hline BG Group & FTSE 350 & $\begin{array}{l}\text { Successful } \\
\text { Efforts }\end{array}$ & Cost & $\begin{array}{l}\text { Intangibles and } \\
\text { non-intangibles }\end{array}$ & YES & YES & $\begin{array}{c}\text { Annual } \\
\text { Report } 2013\end{array}$ \\
\hline BP plc & FTSE 350 & $\begin{array}{l}\text { Successful } \\
\text { Efforts }\end{array}$ & Cost & $\begin{array}{l}\text { Intangibles and } \\
\text { non-intangibles }\end{array}$ & YES & YES & $\begin{array}{c}\text { Annual } \\
\text { Report } 2011\end{array}$ \\
\hline $\begin{array}{l}\text { Cairn Energy } \\
\text { plc }\end{array}$ & FTSE 350 & $\begin{array}{l}\text { Full Cost pre } \\
\quad 2005 \\
\text { Successful } \\
\text { Efforts post } \\
2005\end{array}$ & Cost & $\begin{array}{l}\text { Intangibles and } \\
\text { non-intangibles }\end{array}$ & YES & YES & $\begin{array}{c}\text { Annual } \\
\text { Report } 2013\end{array}$ \\
\hline Enquest & FTSE 350 & $\begin{array}{l}\text { Successful } \\
\text { Efforts }\end{array}$ & Cost & $\begin{array}{l}\text { Intangibles and } \\
\text { non-intangibles }\end{array}$ & YES & YES & $\begin{array}{c}\text { Annual } \\
\text { Report } 2013\end{array}$ \\
\hline $\begin{array}{c}\text { Essar Energy } \\
\text { plc }\end{array}$ & FTSE 350 & $\begin{array}{l}\text { Area of } \\
\text { Interest }\end{array}$ & Cost & $\begin{array}{l}\text { Intangibles and } \\
\text { non-intangibles }\end{array}$ & YES & YES & $\begin{array}{c}\text { Annual } \\
\text { Report } 2013\end{array}$ \\
\hline $\begin{array}{l}\text { Exillion Energy } \\
\text { plc }\end{array}$ & $\begin{array}{c}\text { FTSE } \\
\text { Small Cap }\end{array}$ & $\begin{array}{l}\text { Successful } \\
\text { Efforts }\end{array}$ & Cost & $\begin{array}{l}\text { Intangibles and } \\
\text { non-intangibles }\end{array}$ & YES & YES & $\begin{array}{c}\text { Annual } \\
\text { Report } 2013\end{array}$ \\
\hline
\end{tabular}




\begin{tabular}{|c|c|c|c|c|c|c|c|}
\hline Heritage Oil & FTSE 350 & Full Cost & Cost & $\begin{array}{l}\text { Intangibles and } \\
\text { non-intangibles }\end{array}$ & YES & YES & $\begin{array}{c}\text { Annual } \\
\text { Report } 2013\end{array}$ \\
\hline $\begin{array}{c}\text { JKX Oil \& Gas } \\
\text { plc }\end{array}$ & $\begin{array}{c}\text { FTSE } \\
\text { Small Cap }\end{array}$ & $\begin{array}{l}\text { Successful } \\
\text { Efforts }\end{array}$ & Cost & $\begin{array}{l}\text { Intangibles and } \\
\text { non-intangibles }\end{array}$ & YES & YES & $\begin{array}{c}\text { Annual } \\
\text { Report } 2013\end{array}$ \\
\hline Ophir Energy & FTSE 350 & $\begin{array}{l}\text { Successful } \\
\text { Efforts }\end{array}$ & Cost & $\begin{array}{l}\text { Intangibles and } \\
\text { non-intangibles }\end{array}$ & YES & YES & $\begin{array}{c}\text { Annual } \\
\text { Report } 2013\end{array}$ \\
\hline Premier Oil plc & FTSE 350 & $\begin{array}{l}\text { Full Cost pre } \\
2005 \\
\text { Successful } \\
\text { Efforts post } \\
2005\end{array}$ & Cost & $\begin{array}{l}\text { Intangibles and } \\
\text { non-intangibles }\end{array}$ & YES & YES & $\begin{array}{c}\text { Annual } \\
\text { Report } 2013\end{array}$ \\
\hline $\begin{array}{l}\text { Royal Dutch } \\
\text { Shell }\end{array}$ & FTSE 350 & $\begin{array}{l}\text { Successful } \\
\text { Efforts }\end{array}$ & Cost & $\begin{array}{l}\text { Intangibles and } \\
\text { non-intangibles }\end{array}$ & YES & YES & $\begin{array}{c}\text { Annual } \\
\text { Report } 2013\end{array}$ \\
\hline $\begin{array}{l}\text { Salamander } \\
\text { Energy Plc }\end{array}$ & FTSE 350 & $\begin{array}{l}\text { Successful } \\
\text { Efforts }\end{array}$ & Cost & $\begin{array}{l}\text { Intangibles and } \\
\text { non-intangibles }\end{array}$ & YES & YES & $\begin{array}{c}\text { Annual } \\
\text { Report } 2013\end{array}$ \\
\hline $\begin{array}{c}\text { Soco } \\
\text { International }\end{array}$ & FTSE 350 & Full Cost & Cost & $\begin{array}{l}\text { Intangibles and } \\
\text { non-intangibles }\end{array}$ & YES & YES & $\begin{array}{c}\text { Annual } \\
\text { Report } 2013\end{array}$ \\
\hline Tullow Oil & FTSE 350 & $\begin{array}{l}\text { Successful } \\
\text { Efforts }\end{array}$ & Cost & $\begin{array}{l}\text { Intangibles and } \\
\text { non-intangibles }\end{array}$ & YES & YES & $\begin{array}{c}\text { Annual } \\
\text { Report } 2013\end{array}$ \\
\hline \multicolumn{8}{|c|}{ Panel C: Hang Seng Companies } \\
\hline CNOOC & Hang Seng & $\begin{array}{l}\text { Successful } \\
\text { Efforts }\end{array}$ & Cost & $\begin{array}{l}\text { Intangibles and } \\
\text { non-intangibles }\end{array}$ & YES & YES & $\begin{array}{c}\text { Annual } \\
\text { Report } 2013\end{array}$ \\
\hline PetroChina & Hang Seng & $\begin{array}{l}\text { Successful } \\
\text { Efforts }\end{array}$ & Cost & $\begin{array}{l}\text { Intangibles and } \\
\text { non-intangibles }\end{array}$ & YES & YES & $\begin{array}{c}\text { Annual } \\
\text { Report } 2013\end{array}$ \\
\hline Sinopec Crop & Hang Seng & $\begin{array}{l}\text { Successful } \\
\text { Efforts }\end{array}$ & Cost & $\begin{array}{l}\text { Intangibles and } \\
\text { non-intangibles }\end{array}$ & YES & YES & $\begin{array}{c}\text { Annual } \\
\text { Report } 2013\end{array}$ \\
\hline \multicolumn{8}{|c|}{ Panel D: NYSE Companies } \\
\hline $\begin{array}{l}\text { Advantage Oil } \\
\text { \& Gas Ltd }\end{array}$ & NYSE & $\begin{array}{l}\text { Successful } \\
\text { Efforts }\end{array}$ & Cost & $\begin{array}{l}\text { Intangibles and } \\
\text { non-intangibles }\end{array}$ & YES & YES & $\begin{array}{c}\text { Annual } \\
\text { Report } 2013\end{array}$ \\
\hline $\begin{array}{c}\text { American Eagle } \\
\text { Energy } \\
\text { Corporation }\end{array}$ & NYSE & Full Cost & Cost & $\begin{array}{l}\text { Oil \& Gas } \\
\text { Properties }\end{array}$ & NO & NO & $\begin{array}{c}\text { Annual } \\
\text { Report } 2013\end{array}$ \\
\hline Anadarko & NYSE & $\begin{array}{l}\text { Successful } \\
\text { Efforts }\end{array}$ & Cost & $\begin{array}{l}\text { Exploration and } \\
\text { Production } \\
\text { Properties }\end{array}$ & YES & NO & $\begin{array}{c}\text { Annual } \\
\text { Report } 2012\end{array}$ \\
\hline $\begin{array}{c}\text { Apache } \\
\text { Corporation }\end{array}$ & NYSE & Full Cost & Cost & $\begin{array}{l}\text { Oil and Gas } \\
\text { Properties }\end{array}$ & YES & No & $\begin{array}{c}\text { Annual } \\
\text { Report } 2013\end{array}$ \\
\hline \multicolumn{8}{|c|}{ Panel E: Toronto (TSX) Companies } \\
\hline Husky Energy & $\begin{array}{l}\text { Toronto } \\
\text { Stock } \\
\text { Exchange }\end{array}$ & $\begin{array}{l}\text { Full Cost Pre } \\
2012 \\
\\
\text { Successful } \\
\text { Efforts from } \\
2012\end{array}$ & Cost & $\begin{array}{l}\text { Intangibles and } \\
\text { non-intangibles }\end{array}$ & YES & YES & $\begin{array}{c}\text { Annual } \\
\text { Reports } \\
2010-2013\end{array}$ \\
\hline Lundin & $\begin{array}{l}\text { Toronto } \\
\text { Stock }\end{array}$ & Successful & Cost & Oil and Gas & YES & YES & $\begin{array}{l}\text { Annual } \\
\text { Reports }\end{array}$ \\
\hline
\end{tabular}




\begin{tabular}{|c|c|c|c|c|c|c|c|}
\hline Petroleum & Exchange & Efforts & & Properties & & & 2008- 2013 \\
\hline \multicolumn{8}{|c|}{ Panel F: Fortune Companies } \\
\hline Devon Energy & $\begin{array}{c}\text { Fortune } \\
500\end{array}$ & Full Cost & Cost & $\begin{array}{l}\text { Oil and Gas } \\
\text { Properties }\end{array}$ & YES & NO & $\begin{array}{c}\text { Annual } \\
\text { Report } 2013\end{array}$ \\
\hline \multicolumn{8}{|c|}{ Panel G: ISEQ Companies } \\
\hline Aminex plc & $\begin{array}{l}\text { ISEQ } \\
\text { LSE }\end{array}$ & $\begin{array}{l}\text { Successful } \\
\text { Efforts }\end{array}$ & Cost & $\begin{array}{l}\text { Intangibles and } \\
\text { non-intangibles }\end{array}$ & YES & YES & $\begin{array}{c}\text { Annual } \\
\text { Report } 2012\end{array}$ \\
\hline $\begin{array}{l}\text { Petroceltic plc } \\
\text { (formerly } \\
\text { Melrose) }\end{array}$ & $\begin{array}{l}\text { ISEQ } \\
\text { AIM }\end{array}$ & $\begin{array}{l}\text { Full Cost pre } \\
2005 \\
\\
\text { Successful } \\
\text { Efforts post } \\
2005\end{array}$ & Cost & $\begin{array}{l}\text { Intangibles and } \\
\text { non-intangibles }\end{array}$ & YES & YES & $\begin{array}{c}\text { Annual } \\
\text { Report } 2013\end{array}$ \\
\hline
\end{tabular}

\section{References}

Adelman, M. A. 1996. The Genie Out of the Bottle. Cambridge, MIT Press.

Alfredson, K; Leo, K; Picker, R; Loftus, J; Clark, K; Wise, V. 2009. Applying International Financial Reporting Standards, $2^{\text {nd }}$ Edition, Wiley Publications, Australia.

Bryant, L. 2003. Relative Value Relevance of the Successful Efforts and Full Cost Accounting Methods in the Oil and Gas Industry. Review of Accounting Studies. Vol 8, No 1, pp. 5-28.

Bryman, A and Bell, E. 2007. Business Research Methods, 2nd edition, Oxford University Press, Hong Kong.

Choi, F. D. S. \& Levich, R. M., 1991. 'International Accounting Diversity and Capital Market Decisions' in Handbook of International Accounting, F. D. S. Choi (ed.), John Wiley \& Sons, Inc.

Cortese, L. C. 2011. Standardizing Oil and Gas Accounting in the US in the 1970s: insigts from the perspective of regulatory capture. Accounting History, Vol 16, Issue 4, pp. 403-421.

Cortese, L. C; Irvine, L. H; Kaidonis, A. M. 2009. Extractive Industries Accounting and Economic Consequence: Past, Present and Future. Accounting Forum, Vol 33, pp, 27-37.

Cortese, L. C; Irvine, L. H; Kaidonis, A. M. 2010. Powerful Players: how constituents captured the setting of IFRS6, an accounting standard for the extractive industries. Accounting Forum, Vol. 34, pp, 76-88.

Cortese, L. C and Irvine, L. H. 2010. Investigating International Accounting Standard Setting: the black box of IFRS 6. Research in accounting Regulation, Vol 22, pp. 87-95.

Deakin III, E. B. 1979. An Analysis of Differences between Non-Major Oil Firms Using Successful Efforts and Full Cost Methods. Accounting Review. Vol 54, No 4, pp. 722-743. 
Deloitte. 2009. International Financial Reporting Standards: consideration for the oil and gas industry. Available at: http://www.deloitte.com/assets/DcomUnitedStates/Local\%20Assets/Documents/Energy_us_er/us_er_assurance_IFRS_Oil_Gas_01 0610.pdf. Accessed on 3 July 2014.

Dunne, T. M., Fifield, S. G. M., Finningham, G., Fox, A. M., Hannah, G. M., Helliar, C. V., Power, D. M. and Veneziani, M. 2008. The Implementation of IFRS in the UK, Italy and Ireland, ICAS Research Report.

EN-EU IFRS 6. 2009. International Financial Reporting Standard 6: Exploration for and Evaluation of Mineral Resources. Available at: http://ec.europa.eu/internal_market/accounting/docs/consolidated/ifrs6_en.pdf. Accessed on $29^{\text {th }}$ July 2013.

Ernst \& Young. 2009. US GAAP vs. IFRS- the basic: oil and gas. Available at: http: /ifrsbasics_bb1757_oilandgas_may2009\%20(2).pdf. Accessed on 3 July 2014.

Flory, S. M and Grossman, s. D. 1978. New Oil and gas accounting requirements. The CPA Journal. Vol 48, Issue 5, pp. 39-43.

Gallhofer, S and Haslam, J. 2007. Exploring social, political and economic dimensions of accounting in the global context: the International Accounting Standard Board and accounting disaggregation. Socio-Economic Review. Vol 5, Issue 4, pp. 633-664.

Gallun, R., A; Wright, C., J; Nichols, L. M; Stevenson, J. W. 2001. Fundamentals of Oil \& Gas Accounting, fourth edition, Tulsa, PennWell.

Glaum, M; Schmidt, P; Street, D. L; Vogel, S. 2013. Compliance with IFRS3- and IAS 36required disclosures across 17 European Countries: Company- and country- level determinants. Accounting and Business Research. Vol 43, No 3, pp. 163-204.

Howard, A. W and Harp, A. B. 2009. Oil and Gas Company Valuations. Business Valuation Review. Vol, 28, No. 1, pp. 30-36.

ICAEW. 2014. Worldwide adoption of IFRS. Available at: http://www.icaew.com/en/library/subject-gateways/accounting-standards/worldwideadoption-of-ifrs. Accessed on 9 July 2014.

International Accounting Standard Board (IASB). 2006. Conceptual Framework: Asset Definition. Available at: http://www.ifrs.org/Current-Projects/IASB-Projects/ConceptualFramework/Other-Public-Meetings-Observer-

Notes/Documents/WSSAGENDAPAPER1A.pdf. Accessed on 30 April 2013.

IFRS. 2014. International Financial Reporting Standards (IFRS). Available at: http://www.adoptifrs.org/default.aspx. Accessed on 10 July 2014.

International Financial Reporting Standard (IFRS 6). 2013. Exploration for and Evaluation of Mineral Resources. Available at http://eifrs.ifrs.org/eifrs/bnstandards/en/2013/ifrs6.pdf. Accessed on 27 May 2013.

IFRS Foundation. 2010. International Financial Reporting Standard 6: Exploration for and Evaluation of Mineral Resources. Available at: https://staff.blog.ui.ac.id/martani/files/2011/04/ifrs6.pdf. Accessed on 31 August 2014. 
Jones, B., N. 2010. Intermediate Accounting, $11^{\text {th }}$ Edition, South-Western Cengage Learning, USA.

KPMG. 2005. First Impressions: IFRS 6 Exploration for and Evaluation of Mineral Resources. Available

at: http://www.kpmg.com/BE/en/IssuesAndInsights/ArticlesPublications/FirstImpressions/Docu ments/First-impressions-IFRS-6.pdf , accessed on 23 ${ }^{\text {rd }}$ May 2013.

KPMG. 2007. Assessing the Impact. Adoption of IFRS 6: Exploration for and Evaluation of Mineral Resources by Oil and Gas companies. Available at: http://www.kpmg.com/Ca/en/IssuesAndInsights/ArticlesPublications/Documents/306499AssessingtheImpact interntaional_Accessible.pdf , accessed on 13 ${ }^{\text {th }}$ July 2013.

Luther, R. 1996. The development of accounting regulation in the extractive industries. The International Journal of Accounting. Vol 31, Issue 1, pp. 67-93.

Malmquist, D. H. 1990. Efficient Contracting and the Choice of Accounting Method in the Oil and Gas Industry. Journal of Accounting and Economics. Vol, 12, pp. 173-205.

Mayring, P. 2000. Qualitative Content Analysis. Forum: Qualitative Social Research, Vol 1, No 20, Art 20. Available on: http://www.qualitative-research.net/index.php/fqs/article/view/1089/2385\%3E. [accessed on 01/07/2014].

Nikolai, L. A; Bazley, J. D; Jones, J. P;. 2009. Immediate Accounting. $11^{\text {th }}$ Edition. Stamford Connecticut, USA, South-Western Cengage Learning

Noël, C; Ayayi, G. A; Blum, V. 2010. The European Union's Accounting Policy Analyzed from an Ethical Perspective: the case of petroleum resources, prospecting and evaluation. Critical Perspectives in Accounting. Vol 21, pp. 329-341.

PwC. 2006. Real Time: International Financial Reporting Standards in the mining sector. Available at: http://www.infomine.com/library/publications/docs/PricewaterhouseCoopers2006.pdf.

Accessed on 24 August 2014.

PwC. 2011, Financial Reporting in the Oil and Gas Industry: International Financial Reporting Standards. 2 $2^{\text {nd }}$ edition. Available at: http://www.pwc.com/gx/en/oil-gasenergy/reporting-regulatory-compliance/publications-financial-reporting-oil-gas-

industry.jhtml. Accessed on 1 May 2013.

Roberts, C. Weetman, P. and Gordon P., 2008. International Corporate Reporting: A Comparative Approach (fourth edition), Harlow: Prentice Hall

Saunders, M; Lewis, P; Thornhill, A. 2003. Research Methods for Business Students, 3rd edition, Prentice Hall, Italy.

Stadler, C and Nobes, C. 2014. The Influence of country, industry and topic on IFRS policy choice. ABACUS, A Journal of Accounting, Finance and Business Studies. Vol 50 (4). pp 386-421.

Street, D. L and Gray, S. J. 2004. Observance of International Accounting Standards: factors explaining non-compliance. ACCA Research Report No. 74. London. Certified Accountants Educational Trust. 
Sutton, V. 1993. Harmonisation of International Accounting Standards: is it possible? Journal of Accounting Education. Vol 11, pp. 177-184.

The Institute of Chartered Accountants of India (ICAI). 2013. Guidance Note on accounting for Oil and Gas Production Activities. GN (A) 15 (Revised 2013). New Delhi. Available at: http://220.227.161.86/29140guidance-ogpa.pdf. Accessed on 29 April 2013.

Thomas, A and Ward, M. 2009. Introduction to Financial Accounting. $6^{\text {th }}$ edition. McGrawHill. London.

Whittington, M., 2000. 'Problems in Comparing Financial Performance Across International Boundaries', International Journal of Accounting, Vol. 35, No. 3, pp. 399-413.

Wise, T and Spear, N. 2000. Accounting for Extractive Industries: an Australian Perspective. Petroleum accounting and Financial Management Journal. Vol19, Issue 1, pp. 30-53.

Wise, T and Spear, N. 2002. Factors and Forces of the Extractive Industry Environment, and their Implications for Accounting Measurement and Financial Reporting. Petroleum Accounting and Financial Management Journal. Vol 21, Issue 3, pp1-27.

\section{Annual Reports and Accounts}

American Eagle Energy Corporation. 2013. Annual report and accounts

BP. 2011. Annual report and accounts

Cairn Energy. 2005. Annual report and accounts

Cheniere Energy. 2006. Annual report and accounts

Dana Petroleum. 2011. Annual Report and accounts

Heritage Oil. 2012. Annual report and accounts

Husky Energy. 2010 \& 2013. Annual reports and accounts

JKX. 2012. Annual report and accounts

Melrose Resources. 2005. Annual report and accounts

Ophir Energy. 2012. Annual report and accounts

Premier Oil. 2005 \& 2012. Annual reports and accounts

Salamander Energy. 2012. Annual report and accounts

SOCO International. 2012. Annual report and accounts 


\section{$\underline{\text { Vitae }}$}

Dr Hafez Abdo is a senior lecturer in accounting and finance at the Nottingham Business School (NBS). Hafez joined the NBS in December 2005, where he teaches financial accounting and research method modules in both UG and PG courses. He also supervises a number of Doctorate students. Hafez's main research interest is energy policy, renewable energy options, governance of mineral resources, accounting for oil and gas agreements and accounting for extractive industries. Web page: http://www.ntu.ac.uk/apps/staff_profiles/staff_directory/124600-3/26/hafez_abdo.aspx

Professor Musa Mangena joined the NBS in November 2011; previously, he was a Senior Lecturer in Accounting at the Bradford University School of Management. He has taught on a wide range of postgraduate and undergraduate modules. Musa's research interest is corporate governance, firm disclosure policy and consequences, and behavioral and organizational effects of budgeting and performance measurement systems. Web page: http://www.ntu.ac.uk/apps/staff_profiles/staff_directory/124700-2/26/musa_mangena.aspx

Dr Theresa Dunne is a Lecturer in the Accounting \& Finance Division of the School of Business of the University of Dundee. Theresa teaches on a number of accounting modules in UG and PG courses, and she sits on the editorial board of the Journal of International Accounting, Auditing \& Taxation and the Journal of Qualitative Research in Financial Markets. Theresa's research focuses on accountability, charity accounting and governance, corporate governance, international accounting and reporting, and internet reporting \& XBRL. Web page: http://www.dundee.ac.uk/accountancy/staff/theresadunne/ 